\title{
RIGIDEZ CONSTITUCIONAL E PLURALISMO POLÍTICO
}

\section{RODRIGO BRANDÃO*}

\begin{abstract}
RESUMO: O artigo trata da relação entre rigidez constitucional e pluralismo político. Nesta perspectiva, busca identificar os fatores que conferem rigidez a um regime constitucional e estabelecer conexões entre eles. Por outro lado, o artigo analisa os papéis desempenhados pelos Poderes Judiciário e Legislativo na atualização da Constituição, abordando a questão concernente à definição do departamento responsável pela última palavra sobre o sentido atual da Constituição.

PALAVRAS-CHAVE: Rigidez constitucional, pluralismo político, mudança da Constituição e interpretação constitucional.
\end{abstract}

\begin{abstract}
The text examines the link between constitutional rigidity and political pluralism. So, from this point of view, it analises the elements that ascribe rigidity to a constitutional regime, and it establishes the possible connections linking these factors. On the other hand, the article takes on the roles performed by the Judicial and the Legislative branches in constitutional change, and it examines the question concerning which branch has the last word on the current constitutional meaning.

KEYWORDS: Constitutional rigidity, political pluralism, constitutional change and constitutional interpretation.
\end{abstract}

SUMÁRIO: 1. Introdução; 2. A Democracia Dualista e o Constitucionalismo Brasileiro; 3. Identificação dos elementos que conferem rigidez a um Regime Constitucional; 4. Os caminhos para a alteração da Constituição: Decisões Judiciais versus Emendas Constitucionais; 5. Síntese conclusiva; 6. Bibliografia.

SUMMARY: 1. Introduction; 2. The Dualist Democracy and the Brazilian Constitutionalism; 3. Elements that ascribe rigidity to a Constitutional Regime; 4 . The ways to alter the Constitution: Judicial Decisions versus Constitutional Amendments; 5. Synthesis; 6. Bibliography.

\section{INTRODUÇÃO}

O ponto de partida do presente estudo consiste na tradicional distinção de James Bryce entre as constituições flexíveis e rígidas ${ }^{1}$ : nas primeiras, "as leis constitucionais" só diferem das demais leis pela matéria, mas não pela hierarquia, já que o procedimento apto a produzí-las é idêntico, inexistindo óbices a que as normas constitucionais sejam

\footnotetext{
* Mestre e Doutorando em Direito Público pela UERJ. Professor de Direito Constitucional da EMERJ, da UERJ (pós-graduação), da FGV-RIO (pós-graduação) e do Praetorium, Procurador do Município do Rio de Janeiro e Coordenador do Núcleo de Estudos Constitucionais da PGM-Rio.

${ }^{1}$ BRYCE, James. Constitutiones flexibles y Constitutiones rígidas. Madrid, 1963.
} 
alteradas a qualquer tempo pela autoridade legislativa ordinária. ${ }^{2}$ Assim, no caso de norma constitucional e lei superveniente entrarem em conflito, prevalece a última, precisamente por ser posterior àquela. De efeito, inexistindo supremacia, o conflito há de resolver-se mediante o critério cronológico. Já as constituições rígidas se distinguem pela supremacia hierárquica que ostentam em face das leis em geral, mercê de sujeitarem-se a processo de reforma mais rigoroso do que o atinente à produção de leis, de maneira que, na hipótese de conflito entre "lei constitucional” e lei ordinária, prevalece a primeira, pois, embora anterior, goza de maior hierarquia.

Em que pese à destacada importância exercida por esta classificação, a colocação da questão rigidez versus flexibilidade constitucional em termos dicotômicos fazia algum sentido no período entre as revoluções burguesas e o segundo pós-guerra, pois neste lapso se verificaram tendências antagônicas: enquanto o modelo das constituições rígidas era erigido nos Estados Unidos, na Europa se constatava clara prevalência das constituições flexíveis. Todavia, com o atual fenômeno de expansão das primeiras, a idéia de rigidez constitucional constitui verdadeiro "axioma da consciência jurídica universal”, ao passo que as constituições flexíveis tornaram-se, praticamente, reminiscências históricas. ${ }^{3}$

Se boa parte das atuais constituições ocidentais importou do constitucionalismo norte-americano a noção de rigidez constitucional, da tradição européia extraiu um conteúdo constitucional mais amplo do que o presente na Constituição de 1787; daí Prieto Sanchís afirmar que as constituições contemporâneas são fruto da fusão das respectivas tradições constitucionais. ${ }^{4}$ Segundo o modelo norte-americano, a constituição deveria se limitar à definição das regras do jogo democrático - através de normas de competência e de procedimento -, e a prever poucos direitos fundamentais. A par deste restrito conteúdo normativo, caracteriza-se tal sistema pela afirmação da supremacia da constituição, a qual resta garantida pelo controle jurisdicional de constitucionalidade. Trata-se, portanto, “de um judicialismo estritamente limitado à observância das regras básicas da organização política." 5

Em sentido diverso, coloca-se a concepção européia de constitucionalismo que, fortemente influenciada pelo direito público francês, atribui à constituição uma função mais ampla: caber-lhe-ia não apenas definir as regras do jogo democrático, mas veicular um projeto de transformação política e social, de modo a pré-definir, em maior ou menor intensidade, como o Estado deve proceder em futuras intervenções em determinadas matérias. ${ }^{6}$ Entretanto, a adoção do modelo das constituições flexíveis e a conseqüente inexistência de controle de constitucionalidade acabaram

${ }^{2}$ CANOTILHO, José Joaquim Gomes. Direito Constitucional. Coimbra: Almedina, 1992.

${ }^{3}$ VEGA, Pedro de. La Reforma Constitucional y la Problematica del Poder Constituyente. Madrid: Tecnos, 2000, p. 50. O autor cita como exceções que confirmam a regra, porquanto ainda adotam constituições flexíveis, os constitucionalismos inglês, neozelandês e israelense.

${ }^{4}$ PRIETO SANCHÍS, Luis. Neoconstitucionalismo y ponderación judicial. In: CARBONELL, Miguel. Neoconstitucionalismo(s), Madrid: editorial Trotta, 2003, p. 126.

${ }^{5}$ Ibid., p 125.

${ }^{6}$ FIORAVANTI, Maurizio. Los derechos fundamentales: apuntes de la historia de las constituciones. 4 ed. Madrid: Editorial Trotta, 2003. 
por reconduzir tão ambicioso constitucionalismo a um legalismo, no qual a tutela constitucional dos direitos se dessubstancializara num oco postulado de reserva de lei. Tal modelo restou amplamente rejeitado a partir do segundo pós-guerra, com a constatação da necessidade de estabelecer-se uma vinculação material do Legislador aos direitos fundamentais (v. infra).

Neste dilema entre constituições sem significativo conteúdo normativo material, mas cuja supremacia era garantida pelo controle de constitucionalidade, e constituições com denso conteúdo normativo substantivo, mas que, na prática, consistiam em meros aconselhamentos ao legislador, diante da ausência de mecanismos destinados à sua efetiva garantia, o constitucionalismo contemporâneo optou por uma ousada fusão: constituições com forte conteúdo normativo e cuja supremacia hierárquiconormativa restaria garantida pelo controle jurisdicional de constitucionalidade. ${ }^{7}$

Neste sentido, as Constituições européias do segundo pós-guerra - v.g.: Lei Fundamental de Bonn, de 1949, e as Constituições da Itália de 1947, e da Espanha de 1978 -, e a Constituição brasileira de 1988, acompanhadas da instalação de Tribunais Constitucionais (em 1951 na Alemanha; em 1956 na Itália, e em 1978 da Espanha), revelam nitidamente a tendência a, como reação a barbáries e arbitrariedades cometidas por regimes autoritários (v.g.: nacional-socialismo alemão, fascismo(s) e ditaduras militares), desconfiar dos poderes legitimados pelo voto popular, parecendo o constitucionalismo, com a retirada de valores fundamentais do dia-a-dia do processo político, a melhor solução. Tais Cartas adotaram o mecanismo do controle de constitucionalidade e incorporaram ao texto constitucional um denso conteúdo normativo e moral (i.e. direitos fundamentais). Elas regulam, ademais, um vasto domínio, incidindo, por exemplo, sobre as relações de trabalho, a economia, a saúde, a educação, a cultura, a defesa do consumidor, do meio ambiente e do patrimônio histórico-cultural, a família, etc.

Do exposto podem ser extraídas duas conclusões: (i) a universalização das constituições rígidas revela a necessidade de substituição da classificação dicotômica de James Bryce por uma concepção que enfatize o grau de rigidez de um regime constitucional concreto. Vislumbra-se, portanto, a relação entre flexibilidade e rigidez constitucional não como alternativas reciprocamente excludentes, mas como um gradiente, em cujas extremidades se situam preocupações superlativizadas do constituinte a respeito das necessidades de adaptabilidade e de permanência do projeto constitucional, respectivamente. Nesta seara, a virtude, como sói acontecer, parece residir no meio, porquanto é inequívoca a pertinência da busca de um ponto de equilíbrio entre a abertura da constituição, decorrente da necessidade de adaptá-la à realidade superveniente, de serem corrigidos erros de prognose do constituinte e de conceder-se espaço razoável ao pluralismo político e à mudança democrática nos quadros da constituição, de um lado, e a garantia da estabilidade das instituições políticas e da salvaguarda de consensos constitucionais mínimos que conferem identidade à constituição, em face do aventureirismo de grupos políticos dotados de êxitos eleitorais conjunturais, de outro lado. ${ }^{8}$

\footnotetext{
${ }^{7}$ PRIETO SACHÍS, Luis. Op. cit.

${ }^{8}$ Conferir, a propósito, CANOTILHO, op. cit., p. 151 e seq.
} 
Por outro lado, (ii) a enorme abrangência das constituições contemporâneas e a circunstância de este amplo conteúdo atuar, efetivamente, como barreira à atuação do legislador, denotam que os atuais regimes se caracterizam, em geral, pelo forte grau de rigidez constitucional, na medida em que há um alargamento do espaço dos consensos constitucionais em detrimento do âmbito de livre conformação legislativa.

Parece evidente, contudo, que o equilíbrio entre flexibilidade e rigidez constitucional repercute na relação entre os poderes democraticamente legitimados e o Judiciário, visto que, se compete ao Legislativo adaptar o texto constitucional originário ao contexto atual, deve, a princípio, o Judiciário zelar pela intangibilidade dos referidos consensos mínimos em face de maiorias transitórias. A definição da relação entre rigidez e flexibilidade constitucional, e, via de conseqüência, a distinção entre os papéis desempenhados pelo Legislativo e pelo Judiciário no desenvolvimento da constituição revela questão de forte colorido político, na medida em que consiste em ponto sensível da configuração concreta da separação dos "poderes" no âmbito de uma democracia representativa.

Assim, o presente estudo se destina a identificar os fatores que contribuem para o enrijecimento ou para a flexibilização de um regime constitucional concreto, e, em seguida, aplicá-los ao direito brasileiro, a fim de verificar o seu grau de rigidez e de distinguir as mudanças constitucionais que podem ser feitas por decisão judicial em face daquelas que só podem ser veiculadas por emenda constitucional. Antes, porém, cumpre ser analisada premissa teórica fundamental à tese aqui desenvolvida, qual seja, a aplicabilidade da democracia dualista ao contexto brasileiro.

\section{A DEMOCRACIA DUALISTA E O CONSTITUCIONALISMO}

\section{BRASILEIRO}

O processo de emenda à constituição não deve ser muito fácil nem muito difícil. Um processo de emenda muito fácil, como o presente em constituições flexíveis, cujos requisitos procedimentais são idênticos aos pertinentes à elaboração de leis ordinárias, não distingue matéria constitucional da legislação ordinária, equiparando, via de conseqüência, os poderes constituinte e constituído. Olvida-se, pois, da noção de que o rito de alteração da constituição deve se consubstanciar num processo cujos rigores procedimentais, lentidão, alto nível de participação popular, etc., dotariam-no de especial caráter deliberativo. ${ }^{9}$

Além disto, a primazia absoluta da pretensão de adaptabilidade do texto constitucional à de permanência, que se verifica nas constituições flexíveis, traz em si fundados riscos, por um lado, à estabilidade das instituições políticas e à salvaguarda de elementos constitucionais essenciais, pois ambos ficariam à mercê de conjunturas políticas efêmeras. Por outro lado, apresenta tendencial prejuízo à soberania popular no bojo de democracias representativas, pois a clivagem entre deliberações extraordinárias e ordinárias tem o potencial de evitar que um poder constituído (especialmente o

\footnotetext{
9 V. LUTZ, Donald. Toward a Theory of Constitutional Amendment. In: LEVINSON, Sanford. Responding to Imperfection - The Theory and Practice of Constitutional Amendment, Princeton: Princeton University Press, 1995.
}

DiREITOS FundamentaIS E J JUSTIÇA N 5 - OUT./DEZ. 2008 
Legislativo) monopolize o poder de alterar a constituição, convolando-se, na prática, em poder soberano. ${ }^{10}$

Já um processo de reforma constitucional muito difícil impediria a correção de erros de prognose dos constituintes, desconsiderando a falibilidade humana, ${ }^{11}$ além de não permitir a necessária adaptação do texto constitucional à realidade superveniente, ${ }^{12}$ fatores que causariam, muito provavelmente, a ruptura institucional ou o descumprimento sistemático da constituição.

Como já se pôde entrever, tais considerações partem do pressuposto de uma concepção dualista de democracia. Esta perspectiva, intrinsecamente ligada à história constitucional norte-americana, embora recentemente reconstruída por Bruce Ackerman, ${ }^{13}$ diferencia as políticas constitucional e ordinária. É assaz conhecida a concepção de que as constituições resultam da vontade do povo, enquanto as leis decorreriam da vontade dos seus representantes. Desta feita, as constituições são concebidas como instrumentos de delegação do poder originário e soberano do povo aos poderes

${ }^{10}$ O modelo de Estado de Direito Legalista, prevalecente na Europa Continental do período pós-revolucionário ao segundo pós-guerra, parece corroborar a assertiva em apreço. A propósito, a influência exercida pelo conceito moderno-iluminista de lei sobre este arranjo institucional, que vislumbrava tal espécie normativa como expressão inelutável dos imperativos da razão e da vontade do povo, acabava por reconduzir as manifestações estatais à criação e à aplicação do direito, e, conseqüentemente, à dicotomia função legislativa versus função executiva lato sensu (que abrangia as funções judicial e executiva stricto sensu). Desta hierarquização funcional decorria correlata hierarquização entre os órgãos estatais, de maneira a conceber-se a supremacia da lei e do Parlamento em relação aos poderes Executivo e Judiciário e aos seus respectivos atos. Esta relação superior-subalterno entre os órgãos do Estado implicará, naturalmente, um modelo político-institucional cuja nota distintiva é o monismo do poder legislativo, na medida em que todo o poder político efetivo será concentrado no Parlamento. Das diversas conseqüências do que se expôs, uma é de especial importância para a confirmação da tese afirmada pela democracia dualista: se o Legislador se acha livre de constrangimentos efetivos, na medida em que se atribui a seus atos a natureza de lídima manifestação da soberania, verifica-se uma estranha "soberania de poder constituído". De fato, sendo o Legislador legibus solutus, este órgão estatal se torna autor do seu próprio poder, podendo alterar o direito positivo (inclusive a Constituição) quando e como bem entender, de modo a emitir, incessantemente, uma vontade ilimitada capaz de redefinir a forma de governo, as instituições políticas e o conteúdo dos direitos fundamentais. Desta forma, esta curiosa convolação dos "representantes da nação soberana" em "representantes soberanos da nação” gera uma confusão entre os poderes constituinte e constituídos, e, por conseguinte, a própria inviabilidade do conceito de poder constituinte, o qual, ao menos em sua tradicional formulação de matriz norte-americana, parece vincular-se à superioridade e à pré-estatalidade da vontade do povo sobre a dos poderes constituídos, e, portanto, à noção de rigidez constitucional. Ver FIORAVANTI, Maurizio. Los Derechos Fundamentales - Apuntes de la Historia de las Constituciones. 4 ed. Madrid: Editorial Trotta, 2003; VEGA, Pedro de. La Reforma Constitucional y la Problematica del Poder Constituyente. 5 reimpresión, Madrid: Tecnos, 2000; PIÇARRA, Nuno. A Separação de Poderes como Doutrina e Princípio Constitucional. Coimbra: Coimbra editora. 1989; BRANDÃO, Rodrigo. As culturas liberal e democrática de proteção dos direitos individuais no constitucionalismo clássico. In: Revista de Informação Legislativa n. 175, ano 44 (julho/setembro 2007). Brasília: Senado Federal, Subsecretaria de Edições Técnicas, pp. 233/268. ${ }^{11}$ LUTZ. Donald. In: LEVINSON. Op. cit., pp. 239/240.

${ }^{12}$ VEGA, Pedro de. Ibidem.

${ }^{13}$ Conforme salientado no corpo do texto, o modelo da democracia dualista, embora reconstruído recentemente por Ackerman, em festejada formulação, consubstancia um dado da história constitucional norte-americana, e é constitutivo do pensamento dos Federalistas, notadamente do republicanismo cívico de Madison. Cf. BRITO. Miguel Nogueira. A Constituição Constituinte - Ensaio sobre o Poder de Revisão da Constituição. Coimbra: Coimbra Editora, 2000, pp. 39/40; ACKERMAN, Bruce. We the people: foundations. Cambridge: The Belknap University Press, 1991. 
constituídos, os quais estarão vinculados às competências e mecanismos de controle mútuo estabelecidos neste documento normativo supremo, não podendo, portanto, alterá-los por deliberações ordinárias (v.g.: leis, atos administrativos e decisões judiciais). ${ }^{14}$ Afigura-se corolário natural do exposto que, na hipótese de conflito entre constituição e lei, a primeira prevaleça, mercê de sua maior hierarquia, considerandose a lei inconstitucional, portanto, nula de pleno direito. ${ }^{15}$

Note-se que a superioridade da manifestação das Convenções Constitucionais sobre as do Parlamento e, via de conseqüência, da constituição sobre as leis, não decorre apenas do consentimento do We the people a que se refere a Constituição americana (fonte), mas também do ambiente especial de deliberação presente quando o povo é chamado a atuar ativamente no processo político (qualidade intrínseca à deliberação constitucional).

A propósito, nos momentos de política constitucional (constitucional politics) verifica-se não apenas o exercício de uma cidadania ativa, mas, especialmente, que o povo logra se desvencilhar da tendência natural de perseguir os seus interesses particulares e imediatos, de agir passional e irracionalmente, atuando, ao revés, tendo em vista a realização do bem comum e de expectativas de longo prazo. Em poucas palavras: nos raros momentos constitucionais, o ambiente de insegurança e de incerteza que os cerca torna mais factível a concretização da aspiração republicana da virtude ética dos cidadãos em sua atuação política. Assim, este processo deliberativo eticamente superior retira princípios básicos de justiça do alcance de maiorias conjunturais, as quais, atuando no âmbito da política ordinária (normal politics), estarão sujeitas a sucumbir à atuação auto-interessada, em prejuízo aos direitos das minorias. ${ }^{16} 17$

\footnotetext{
${ }^{14}$ Cf. MADISON, James. O Federalista. Campinas: Russel, 2003, no 49 e 53, pp. 313 e 331/332.

${ }^{15}$ HAMILTON, Alexander. O Federalista. Op. cit., n. 78, p. 470.

${ }^{16}$ Este modo de agir se revela no conceito de facção, a qual, segundo Madison, corresponderia: “(a)um grupo de cidadãos, representando quer a maioria, quer a minoria do conjunto, unido e agindo sob um impulso comum de sentimentos ou interesses contrários aos direitos dos outros cidadãos ou aos interesses permanentes e coletivos da comunidade". Salienta, ainda, que essa forma egoística de agir seria inerente à natureza humana em um regime de liberdade. V. MADISON, James. O Federalista, $\mathrm{n}^{\circ}$ 10. Campinas: Russell, 2003, p. 78.

${ }^{17}$ Uma forma sugestiva de ilustrar tal processo político-deliberativo qualitativamente superior consiste na utilização da noção de pré-compromisso constitucional. Tal conceito, desenvolvido por Jon Elster e ilustrada pelo conto mítico de Ulisses e as Sereias, relatado por Homero no Livro XII da Odisséia, segundo o qual Ulisses, tendo sido advertido por Circê que, ao passar pela ilha das sereias acabaria por sucumbir ao seu canto irresistível, ordenou aos seus comandados que o amarrassem ao mastro, permitindo, assim, que não cedesse àquela tentação irresistível.

Os pré-compromissos constitucionais se consubstanciam, portanto, em estratégias de auto-incapacitação, extraídas dos pré-compromissos individuais - cogite-se, por exemplo, que pessoa com dificuldades de acordar cedo coloque seu despertador longe da cama, para evitar que o desligue e continue a dormir -, por meio das quais um indivíduo ou um povo, em um momento de lucidez, afasta a possibilidade de adotar decisões míopes a que estaria tendencialmente sujeito em momentos de debilidade da vontade ou de racionalidade distorcida, logrando, desta forma, afastar-se de tentações ou fraquezas e, via de conseqüência, atingir os seus verdadeiros interesses.V. ELSTER, Jon. Ulysses and the Sirens: studies in rationality and irracionality. Great Britain: Cambridge University Press, 1979; BAYÓN, Juan Carlos. Derechos, democracia y constitución. In: LAPORTA, Francisco. Constitución: problemas filosóficos. Madrid: Centro de Estudios Políticos y Constitucionales, 2003, p. 410. Ver, também, HOLMES, Stephen. Pre-commitment and the paradox of democracy. In: HOLMES, Stephen. Passions and constraints: on the theory of liberal democracy. Chicago: University of Chicago Press, pp. 134/178.
} 
Neste ponto, é bem de ver que o atual processo de universalização dos conceitos de rigidez constitucional e de controle de constitucionalidade, e a circunstância de ambas as noções terem guarida no direito constitucional positivo brasileiro, confirmam a pertinência da adoção da premissa da democracia dualista no Brasil. E mais: uma análise atenta da realidade político-institucional pátria parece confirmar o que se expôs. Com efeito, apesar das diversas vicissitudes da atuação da Assembléia Nacional Constituinte que estenderam, sobremaneira, a abrangência do texto constitucional brasileiro, a Carta de 1988 se originou de processo que contou com intensa participação da sociedade civil, sendo justamente proclamada de "Constituição Cidadã” por Ulysses Guimarães, Presidente da Assembléia Constituinte. ${ }^{18}$

Ademais, a Constituição de 1988 se consubstanciou no marco jurídico do processo de redemocratização do país, e, naturalmente, os constituintes optaram por uma “Constituição substantiva”, cujo denso conteúdo moral se revelou, notadamente, no mais amplo elenco de direitos e garantias fundamentais já positivado no Brasil, o qual abrange os direitos de primeira, segunda e terceira "geração". Neste viés, não se limitou a fixar competências e limites à atuação dos poderes públicos, como as Constituições-Garantia do constitucionalismo liberal, mas veiculou "um amplo e generoso projeto de transformação da sociedade brasileira, no sentido da promoção da justiça social, da liberdade real e da igualdade substantiva”, ${ }^{19}$ qualificando-se como dirigente.

Ainda que temperados pelo lado menos virtuoso da constituição, tais fatores conduzem à conclusão de que, no Brasil, não se afigura despropositado atribuir ao processo constituinte e ao seu fruto uma qualidade deliberativa superior aos processos deliberativos dominados pelo Parlamento e pelo Executivo. Nem mesmo o processo de reforma disciplinado no art. 60 da Constituição de 1988, apesar de sujeito aos limites materiais, formais e circunstanciais estabelecidos nos parágrafos do aludido dispositivo, parece atingir o nível deliberativo obtido no processo constituinte brasileiro. De fato, o procedimento de emenda à constituição, além de distante do povo, na medida em que monopolizado pelo Executivo e pelo Legislativo, apresenta nível não muito alto de dificuldade, especialmente nas hipóteses em que a iniciativa é do Presidente ou de 1/3 (um terço) dos membros das Casas Legislativas.

Desta feita, não causa surpresa o fato de os governos de ocasião terem se desincumbido - muitas vezes, infelizmente, mediante expedientes não republicanos de obter a maioria de três quintos necessária para a reforma da constituição. A conseqüência disto, como era de se esperar no âmbito de uma constituição casuísta e prolixa, ${ }^{20}$ foi a aprovação de uma profusão de emendas (cinqüenta e seis, além das seis emendas de revisão) em um curto espaço de tempo (vinte anos), muitas incidentes sobre matérias que carecem de dignidade constitucional, como v.g.: EC 11/96:

${ }^{18}$ SARMENTO. A ubiqüidade constitucional: os dois lados da moeda. Op. cit., p. 177 e seq. Para uma análise mais ampla do processo constituinte brasileiro, notadamente das alvitradas vicissitudes, ver BARROSO, Luís Roberto. Doze anos da constituição brasileira de 1988 (Uma breve e acidentada história de sucesso). Temas de direito constitucional. Rio de Janeiro: Renovar, 2001, pp. 03/49.

${ }^{19}$ SARMENTO. Op. cit., p. 179.

${ }^{20}$ BARROSO. Op. cit., p. 13. 
contratação de professores estrangeiros por Universidades brasileiras; EC 10/96, 14/96, 17/97, 29/2000 e 31/2000: criação de fundos financeiros; EC 18/98: regime jurídico de militares; EC 24/99: representação classista na Justiça do Trabalho; EC 25/2000: limites de despesas de Câmaras dos Vereadores; EC 28/2000: prazo de prescrição de créditos trabalhistas; EC 30/2000 e 37/2002: regras sobre precatórios; EC 34/2001: cumulação de cargos públicos; EC 38/2002: vínculo funcional de servidores de território federal extinto; EC 51/2006: convalidação da contratação de agentes de combate a endemias independentemente da aprovação em concurso público, etc. Resta nítido que esta crítica ao potencial deliberativo do processo de reforma revelar-se-ia ainda mais forte em face do processo legislativo ordinário, já que ausentes os rigores procedimentais aplicáveis àquele.

O destaque conferido ao maior potencial deliberativo do processo de criação de uma constituição em países com alguma tradição democrática não nos deve conduzir ao equívoco de conferir às deliberações constitucionais uma aura de santidade. Os diversos exemplos de "entrincheiramento constitucional de privilégios” nos levam a considerar, com seriedade, a advertência de Jeremy Waldron de que, sob o pressuposto de inexistir uma resposta certa acerca do conteúdo de princípios constitucionais vagos - como, por exemplo, os direitos fundamentais -, a positivação constitucional de direitos se consubstancia em atitude que combina autoconfiança e desconfiança despropositadas: autoconfiança, no sentido de estar certo de que aquilo que foi retirado do processo deliberativo ordinário é, de fato, matéria de direito fundamental, assim como de que inexistirão controvérsias a respeito da sua interpretação e aplicação; desconfiança, pois está implícita na positivação constitucional a noção de que qualquer visão alternativa adotada pelo legislador em um ou dez anos será equivocada, de maneira que a perspectiva do seu autor deve ser colocada acima do alcance da revisão legislativa. $^{21}$

Confira-se hipótese em que a crítica de Waldron cai como uma luva: Ruslan Khasbulatov, Presidente do Soviet Supremo Russo, antes de ser deposto por Boris Yeltsin do seu cargo, tinha em seu staff um grupo de constitucionalistas cujo trabalho cingia-se a indicar-lhe quando os projetos de lei de sua autoria conflitavam com a constituição. Percebido o contraste, Khasbulatov, sem cerimônia alguma, automaticamente convolava o projeto de lei em projeto de emenda constitucional, submetendo-o ao processo respectivo. ${ }^{22}$ Com acuidade, Jon Elster salienta que no Leste Europeu a constituição é vista como um instrumento de ação política (instrument of action), e não como uma estrutura de governo (framework of government). ${ }^{23}$

Tais vicissitudes não se limitam ao Leste Europeu, mas também se fizeram sentir no Brasil. De fato, depreende-se do lado menos virtuoso do processo constituinte brasileiro uma luta entre diversos grupos que, desconfiados do legislador, desejavam

${ }^{21}$ WALDRON, Jeremy. Law and disagreement. Oxford: Oxford University Press, 2004, p. 222.

22 SUNSTEIN, Cass; HOLMES, Stephen. “The Politics of Constitutional Revision in Eastern Europe”. In: SANFORD, Levinson. Responding to Imperfection - The Theory and Practice of Constitutional Amendment. Princeton: Princeton University Press, 1995, p. 281.

${ }^{23}$ ELSTER, Jon. Constitucionalism in Eastern Europe: an introduction. University of Chicago Law Review 58 (1991): 470. 
cristalizar no texto constitucional, da forma mais minuciosa possível, os seus interesses particulares. A conseqüência inevitável é que a Constituição de 1988, a par de excessivamente extensa e detalhista, serviu-se ao entrincheiramento constitucional de posições de vantagem em favor de donos de cartório, membros do Judiciário e do Ministério Público, policiais, servidores civis e militares, etc. ${ }^{24}$

Cumpre indagar, portanto, se tais patologias infirmam a assertiva antes sustentada, a respeito de a premissa da democracia dualista se afigurar pertinente à realidade político-constitucional brasileira. Seria aplicável ao Brasil a advertência formulada por Cass Sustein e Stephen Holmes no contexto das Constituições pós-soviéticas, de que um grau de rigidez constitucional apto a promover uma clara distinção entre as políticas constitucional e ordinária seria inapropriado para países despidos de tradição democrático-liberal, sendo inevitável e mesmo conveniente uma certa “ordinarização” da constituição?

A propósito, Sustein e Holmes, tendo em vista a falta de tradição democrática no Leste Europeu, defendem que as constituições destes países devem apresentar um nível suave de rigidez constitucional (processo fácil de reforma constitucional, forte dose de judicial self-restraint e inclusão no rol de cláusulas pétreas apenas de direitos fundamentais e de aspectos estruturais do Estado de Direito). Tal flexibilização do regime constitucional permitiria, paradoxalmente, uma estabilidade, pois evitaria que os derrotados na deliberação constituinte buscassem uma ruptura institucional, e viabilizaria a criação de uma cultura de deliberação democrática a respeito de assuntos constitucionais, a par de legitimar um Parlamento recém liberto dos grilhões de um regime autocrático. ${ }^{25}$

Não há dúvidas de que a utilização da constituição não apenas como repositório das regras do jogo democrático e de direitos fundamentais, mas também como instrumento de ação política (e, pior, muitas vezes como instrumento de proteção reforçada de interesses corporativos), se consubstancia em ponto de contato entre as experiências constitucionais brasileira e do Leste Europeu. Entretanto, num cômputo geral o processo constituinte apresenta maior qualidade deliberativa do que o processo legislativo (ordinário e constituinte-reformador), para além de a democracia brasileira, apesar de enfraquecida por alguns interlúdios de autoritarismo, apresentar vigor superior às incipientes tentativas de introdução deste regime político na maioria dos países do Leste Europeu, como, aliás, comprova o período pós-88, cuja Constituição sobreviveu ao impedimento de um presidente eleito pelo povo sem quebra da legalidade constitucional.

Portanto, da conjugação dos lados mais e menos virtuosos da Carta de 1988 resulta uma visão dessacralizada acerca dos seus limites e possibilidades que, todavia, não recai num ceticismo absoluto como o de Waldron, para quem a previsão constitucional de direitos consiste na petrificação de uma visão particular acerca do seu conteúdo esposada por um grupo social mais bem articulado. Ao contrário, comunga-se do otimismo de Rawls acerca da viabilidade de obter-se, entre cidadãos

\footnotetext{
${ }^{24}$ Cf.. SARMENTO. Op. cit., item 4, intitulado Democracia e Banalização Constitucional.

${ }^{25}$ SUNSTEIN, Cass; HOLMES, Stephen. Op. cit.
} 
dotados de um senso de justiça, um consenso sobreposto entre doutrinas abrangentes e razoáveis, de modo a que as Cortes possam proferir, mediante o emprego da razão pública, uma resposta politicamente neutra a respeito do núcleo essencial dos princípios constitucionais de maior vagueza. ${ }^{26}$

Entretanto, impende perquirir quais elementos que, ao lado do grau de dificuldade do processo de reforma à constituição, contribuem para o enrijecimento do projeto constitucional brasileiro, a fim de verificar se a disciplina de um amplo leque de matérias no bojo de uma constituição rígida, com a conseqüente sujeição da sua alteração à supermaioria necessária à aprovação de uma emenda constitucional, significa excessiva vinculação das gerações pós-88 às normas estabelecidas pela geração constituinte, em verdadeiro "governo dos mortos sobre os vivos”. Além disto, convém verificar se, a partir da aferição do grau de rigidez do regime constitucional brasileiro, é possível construir determinados vetores exegéticos aptos a demarcar um espaço em que a atuação do Judiciário na invalidação de decisões do Parlamento, apesar de contramajoritária, se afigura legítima no contexto de uma democracia.

Para se atingir tal desiderato far-se-á uso da proposta de uma teoria geral das emendas constitucionais, formulada por Donald Lutz, ${ }^{27}$ com lastro em dados empíricos atinentes a características do texto constitucional, ao número de emendas e de substituição de constituições, colhidos das experiências constitucionais dos cinqüenta Estados dos EUA e de trinta Nações soberanas.

\section{IDENTIFICAÇÃO DOS ELEMENTOS QUE CONFEREM RIGIDEZ A UM REGIME CONSTITUCIONAL}

Já se teve a oportunidade de salientar que o nível de dificuldade do processo de reforma constitucional se revela de inegável valia para a aferição do grau de rigidez do regime constitucional respectivo. Resta-nos perquirir os demais fatores que contribuem para o enrijecimento ou para a flexibilização do sistema constitucional em tela, bem como estabelecer ilações a respeito das suas possíveis combinações. À guisa de situações-problema, cumpre indagar se um documento constitucional extenso, abrangente, detalhado e sujeito a um procedimento relativamente fácil de emenda, se afigura mais rígido do que um sistema jurídico em cujo vértice se situe uma constituição que, embora sintética, tenha a sua alteração condicionada a um processo rigoroso. A propósito, é possível mensurar o grau de dificuldade do processo de reforma à constituição? Há alguma relação entre o nível de dificuldade do processo de reforma e o grau de ativismo judicial na atualização da constituição por mecanismo informal de reforma (mutação constitucional)? ${ }^{28} \mathrm{O}$ caráter mais ou

\footnotetext{
${ }^{26}$ WALDRON, Jeremy. Op. cit; RAWLS, John. Op. Cit.

${ }^{27}$ LUTZ, Donald. Toward a Theory of Constitutional Amendment. In: LEVINSON, Sanford. Responding to Imperfection - The Theory and Practice of Constitutional Amendment. Princeton: Princeton University Press, 1995, pp. 237/274.

${ }^{28}$ Salienta Ana Cândida Cunha Ferraz que mutação constitucional “consiste na alteração, não da letra ou do texto expresso, mas do significado, do sentido e do alcance das disposições constitucionais, através ora da interpretação judicial, ora dos costumes, ora das leis, alterações essas que, em geral, se processam lentamente, e só se tornam claramente perceptíveis quando se compara o entendimento atribuído às cláusulas constitucionais em momentos diferentes, cronologicamente afastados um do outro, ou em épocas distintas
} 
menos “construtivista” da teoria de interpretação constitucional prevalecente na Suprema Corte consiste em fator de aumento ou de suavização do nível de rigidez constitucional? É possível delimitar os espaços ocupados pelo Congresso Nacional e pelo Judiciário no tocante à atualização da constituição, bem como estabelecer inter-relações entre os respectivos processos?

Crê-se que a teoria geral das emendas constitucionais formulada por Donald Lutz pode trazer elementos importantes para a construção de respostas consistentes a tais questões. Como premissas à sua concepção, o Professor da Universidade de Houston salienta que (i) todo regime político necessita ser modificado em virtude de alterações na realidade a ele subjacente. Ademais, (ii) qualquer sistema que disponha de constituição normativa, assim entendida a norma superior que efetivamente limita e legitima o processo político, ${ }^{29}$ necessita que as alterações por ela sofridas se reflitam na constituição. Destas assertivas decorre que as (iii) constituições exigem alterações regulares, mediante processos formais ou informais de reforma, sob pena de descolarem-se da realidade, com efeitos deletérios à sua força normativa.

Como corolário do exposto, Lutz desfaz mito corrente na teoria constitucional, segundo o qual as constituições "mais saudáveis" seriam aquelas que, não obstante a longa duração, sujeitaram-se a poucas emendas. Por sua vez, as constituições que sofreram muitas modificações formais tendem a ser desqualificadas como normas que "não deram certo". Apesar de um número excessivo de mudanças causar, de fato, sérios prejuízos à força normativa da constituição e ao despertar de um sentimento constitucional no povo, porquanto retira da constituição a respeitabilidade e a efetividade que só o tempo tem o condão de lhe conferir, a circunstância de, ao menos, se buscar uma alteração formal no texto constitucional, em detrimento de uma alternativa extraconstitucional, denota alguma deferência ao texto constitucional, quiçá em alento ao constitucionalismo brasileiro. Neste viés, um índice de emendas muito baixo pode significar o descumprimento sistemático da constituição, com o seu descolamento da realidade subjacente, ou que a sua atualização está sendo veiculada por mecanismo informal de mudança (mutação), especialmente por obra do Judiciário. Se a primeira hipótese se revela ruinosa para a força normativa da constituição, a segunda gera sensível restrição à democracia, pois alteração formal e mutação constitucional por obra do Judiciário revelam um compromisso decrescente com a soberania popular. $^{30}$

Assim, o fato de uma constituição ser levada a sério deve ser diagnosticado a partir de um "índice de emendabilidade" razoável, assim entendida a média de emendas aprovadas por ano que não se revele excessivamente alta ou baixa.

e diante de circunstâncias diversas.” Ressalte-se que abordaremos tão-somente a mutação constitucional por interpretação judicial, dados os limites deste trabalho e a primazia do Judiciário na alteração informal da Constituição. FERRAZ, Ana Cândida Cunha. Processos informais de mudança da constituição. São Paulo: Editora Max Limonad, 1986, p. 9.

${ }^{29}$ LOEWENSTEIN, Karl. Teoría de la constitución. 2 ed. Barcelona: Editorial Ariel, Barcelona, 1976, p. 216 et seq. Faz-se mister enfatizar que a teoria de Lutz se erige sobre o pressuposto do caráter normativo das respectivas constituições.

${ }^{30}$ LUTZ. Op. cit., p. 241. 
Lastreado nos dados antes referidos, Lutz formula alguns standards, que podem ser divididos em dois grupos: o primeiro, composto por quatro proposições, destina-se a demonstrar a existência de uma relação empírica entre os índices de emendabilidade e de substituição total das constituições, enquanto as quatro outras proposições que compõem o segundo grupo se referem às relações travadas entre os métodos formais e informais de alteração constitucional. São elas:

(i) Quanto mais longa a constituição, maior o índice de emendabilidade, e quanto mais curta a constituição, menor o índice;

(ii) Quanto mais funções governamentais tratadas na constituição, mais longa ela será, e maior será o índice de emendas;

(iii) Quanto mais difícil for o processo de emenda, menor será o índice, quanto mais fácil for o processo de emenda, maior será o índice;

(iv) Quanto mais longe o índice de emendas estiver do ideal, para cima ou para baixo, maior a probabilidade de ocorrer a substituição total da constituição, e, portanto, de a sua duração ser menor. Inversamente, quanto mais perto o índice de emendas estiver do ideal, menor a probabilidade de substituição total da constituição, e maior será a sua duração.

(v) Um baixo índice de emendas associado à longa duração da constituição sugere, intensamente, o uso de métodos informais de alteração da constituição em detrimento dos formais, notadamente em favor da atuação do Judiciário.

(vi) Na ausência de um alto índice de substituição total, quanto menor for o índice de emendabilidade, mais provável que o processo de revisão seja dominado pelo Judiciário.

(vii) Quanto maior for o índice de alteração formal, afigura-se (a) menos provável que a constituição seja vista como lei superior (higher law), (b) menos clara a distinção entre matéria constitucional e legislação normal, (c) mais provável de a constituição ser vista como um Código, e (d) mais provável que o processo de emendas seja dominado pela legislatura.

(viii) Quanto mais importante for o papel do Judiciário na revisão da constituição, menos provável é a adoção de teorias de interpretação constitucional não construtivistas. Neste viés, um processo relativamente difícil de alteração da constituição favorecerá a utilização de teorias de interpretação constitucional que sujeitem o Judiciário a limites mais fluidos, enquanto um processo pouco rigoroso de alteração da constituição está associado a teorias de interpretação constitucional de caráter restritivo.

Lutz considera que o índice ideal de emendabilidade se encontra entre 0.76 a 1.00 emendas/ano, para as Constituições dos Estados dos EUA, e entre 1.00 e 1.50 emendas/ano, para as Constituições Nacionais, porquanto as constituições que se inserem neste âmbito apresentam maior longevidade, sem que esta se dê à custa da sua alteração formal quando ela se fizer necessária. Ao contrário, as constituições que se distanciam deste espectro para cima ou para baixo, isto é, que possuem índice de emendabilidade superior ou inferior ao ideal, apresentam menor média de duração.

Há, contudo, questões de suma importância para a elucidação dos fatores que 
contribuem para a aferição do grau de rigidez constitucional de um regime constitucional concreto, as quais serão formuladas a seguir.

3.1 Em uma análise global, quais elementos de um determinado sistema constitucional contribuem para o seu enrijecimento?

Ao nosso ver, as duas primeiras proposições de Lutz, apesar de intuitivas, podem fornecer insights valiosos para a resposta à pergunta em tela. Afigura-se natural que, quanto mais extenso e abrangente for um texto constitucional, mais cedo boa parte das suas disposições ficará obsoleta. Evidentemente que tal circunstância intensifica a rigidez constitucional, na medida em que o amplo espectro de matérias alçadas à constituição gozará da rigidez que lhe é inerente, exigindo supermaiorias para a sua alteração. Assim, as gerações pós-constituintes não poderão alterar este amplo rol de disposições constitucionais mediante simples deliberação majoritária. Concede-se, pois, às minorias um amplo poder de veto sobre matérias política e moralmente relevantes, o qual não se pode assegurar que será exercido para a proteção dos seus direitos fundamentais, podendo servir-se, inversamente, à consolidação de situações de privilégio.

A par da abrangência e da extensão do texto constitucional, saliente-se que a forma de positivação das normas constitucionais também influenciará na aferição do grau de rigidez, vez que uma constituição na qual preponderem normas dotadas de forte densidade semântica (ex: positivadas sob a forma de regras), apresentará reduzida liberdade de conformação do intérprete, tendo em vista que o elemento semântico tende a atuar, nesse particular, como limite. ${ }^{31}$

Em desenvolvimento a tal assertiva, convém destacar que as regras são normas imediatamente descritivas, na medida em que, por descreverem a conduta a ser adotada por seu destinatário, a sua aplicação, normalmente, pressupõe a subsunção de fatos concretos à hipótese de incidência nela prevista. ${ }^{32}$ Já os princípios assumem a natureza de normas imediatamente finalísticas, visto que não descrevem desde logo o comportamento exigível do destinatário, mas um estado de coisas para cuja consecução é necessária a adoção de determinados comportamentos. À míngua da descrição precisa das condutas nos respectivos enunciados normativos, caberá ao intérprete inferir as condutas cujos efeitos promovam, gradualmente, o estado de coisas preconizado pelo princípio. ${ }^{33}$ Portanto, no cotejo entre a aplicação de princípios e regras, afigura-se nítida a maior dose de “construtivismo" inerente à primeira atividade exegética, ante a menor vinculação do intérprete aos limites semânticos do respectivo enunciado normativo.

Resulta do exposto que uma ordem constitucional extensa e abrangente, onde preponderem as regras sobre os princípios, ao retirar um amplo e pormenorizado

\footnotetext{
${ }^{31}$ O elemento gramatical “delimita o espaço dentro do qual o intérprete vai operar”, pois "a mesma linguagem que confere abertura ao intérprete há de figurar como limite máximo de sua atividade criadora.” BARROSO, Luís Roberto. Interpretação e aplicação da constituição. 3 ed. Rio de Janeiro: Renovar, 1999, p. 129.

${ }^{32}$ Sobre a possibilidade, em caráter excepcional, de superação de regras, ver ÁVILA, Humberto Bergman.

Teoria dos Princípios - da definição à aplicação dos princípios jurídicos. 5 ed. São Paulo: Malheiros Editores, 2006.

${ }^{33}$ ÁVILA, Humberto. Ibid. p. 63 et. seq.
} 
leque de matérias do alcance do legislador ordinário, apresenta, prima facie, menor abertura, e via de conseqüência, menor espaço de conformação legislativa. Alarga-se, pois, o espaço dos consensos constitucionais em detrimento do pluralismo político, circunstância que tende a privilegiar o ideal de permanência ao de adaptabilidade do projeto constitucional. Assim, pode-se concluir que, a princípio, quanto mais extenso, abrangente e denso for o conteúdo normativo da constituição, mais se constrange a liberdade do legislador, e maior será a rigidez constitucional e a probabilidade de aumento do índice de alteração formal.

Cumpre, contudo, enfatizar o caráter prima facie desta assertiva, na medida em que a sua corroboração pressupõe que se perscrute o grau de ativismo judicial na tutela de normas constitucionais de maior vagueza, sobretudo dos princípios constitucionais, algo que dependerá, intensamente, da cultura jurídica e política de cada país, ${ }^{34}$ e, mais especificamente, da confiança depositada no Judiciário e no Legislativo. Explica-se: soa intuitivo que, competindo a juízes e legisladores a concretização da constituição, uma postura excessivamente ativista do Judiciário - p. ex., na invalidação de decisões majoritárias e supermajoritárias do Parlamento (leis e emendas constitucionais) com lastro em princípios morais abstratos, como a proporcionalidade, a isonomia, a segurança jurídica, etc. -, significaria um avanço, por instituição contramajoritária, no âmbito de poderes conferidos ao órgão representativo do povo. Tal atitude, a par de potencialmente atentar contra a separação de poderes e o princípio democrático, aumentaria sobremaneira o nível de rigidez constitucional do respectivo regime.

Daí porque uma resposta adequada à questão do nível de rigidez constitucional de um sistema constitucional concreto pressupõe que se transcenda a análise das características gerais do direito constitucional positivo, abordando-se o debate afeto à relação entre as teorias de hermenêutica constitucional e a dificuldade contramajoritária do Judiciário, tópico que será abordado na resposta dada à questão 3.4.

3.2 Há relação entre o grau de dificuldade do processo de reforma da constituição e o nível de rigidez constitucional?

A relação diretamente proporcional existente entre o nível de dificuldade do processo de emenda e o grau de rigidez constitucional é velha conhecida da teoria constitucional, consistindo em forma-padrão de aproximação da matéria. Com efeito, revela-se nítido que, quanto mais "fácil" for o processo de emenda constitucional, maior ênfase será dada à adaptabilidade da constituição em detrimento da sua permanência, e vice-versa. Constatou-se linhas acima que, com a superação do modelo das constituições flexíveis a partir do segundo pós-guerra, a tendência generalizada do constitucionalismo contemporâneo é a adoção de algum nível de rigidez, com a previsão de processo de emenda mais “difícil” do que o alusivo à produção de leis ordinárias. Diversos fatores, entretanto, contribuem para a aferição do grau de dificuldade do processo em apreço.

\footnotetext{
${ }^{34}$ Note-se que o pós-positivismo, especialmente na vertente da Teoria dos Princípios, cuja importância no direito brasileiro é evidenciada pela reverência da doutrina e da jurisprudência pátrias às concepções seminais de Ronald Dworkin e Robert Alexy, tem sensível pendor judicialista. V. ALEXY, Robert. Teoría de los Derechos Fundamentales. Madrid: Centro de Estudios Constitucionales, 1997; DWORKIN, Ronald. Levando os Direitos a Sério. São Paulo: Martins Fontes, 2002.
} 
A propósito, Donald Lutz, a partir de dados referentes às Constituições dos Estados dos EUA, elaborou um índice de dificuldade dos processos de emenda. Tendo como referência o índice 1.00 para o processo de aprovação de emendas por maiorias simples num só turno, em Legislativos Bicamerais, e fundado na relação estabelecida entre setenta variáveis que imprimiam maior rigor ao processo e a repercussão da introdução destes fatores no número de emendas/ano (índice de emendabilidade), atribuiu valores a tais elementos, os quais, em suas palavras, "cobrem virtualmente todas as combinações de processos de emenda existentes no mundo." ${ }^{, 35}$ Confira-se o respectivo quadro: ${ }^{36}$

Competência e procedimento da iniciativa Incremento da dificuldade

Órgão administrativo .................................................................................. + 0.25

Grupo de pessoas especialmente designadas ....................................................... + +0.50

Corpo de representantes eleitos ............................................................................. + 0.75

Legislatura unicameral:

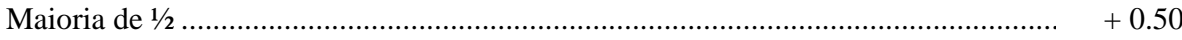

Maioria de $1 / 2$ (dois turnos) ............................................................................. + 0.50

Maioria absoluta ...................................................................................... + 0.65

Maioria absoluta (dois turnos) ........................................................................ + 0.65

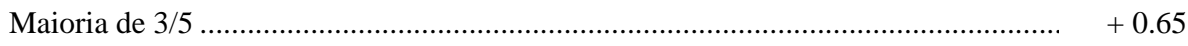

Maioria de $3 / 5$ (dois turnos) ……....................................................................... + 0.65

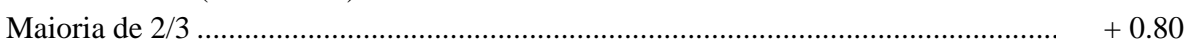

Maioria de $3 / 4$................................................................................................ + 0.90

Maioria de 2/3 (dois turnos) ................................................................................ + +1.75

Se uma eleição é requerida entre os turnos de votação............................................... + + 0.25

Legislatura bicameral:

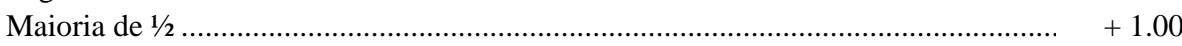

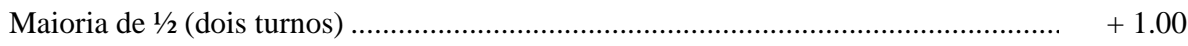

Maioria absoluta ............................................................................................ +1.25

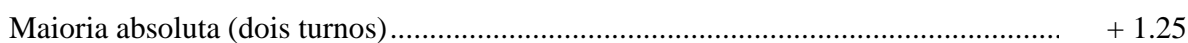

Maioria de $3 / 5$........................................................................................ + +1.25

Maioria de $3 / 5$ (dois turnos) ............................................................................ + +1.25

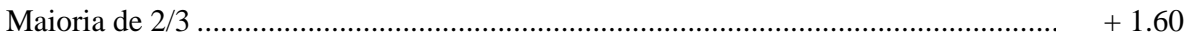

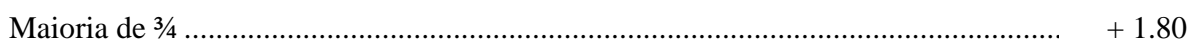

Maioria de 2/3 (dois turnos) .................................................................................... + +3.55

Se uma eleição é requerida entre os turnos de votação................................................ + +0.50

Petição de 0 a 250.000 eleitores .............................................................................. + 3.00

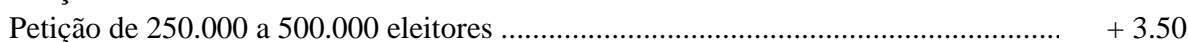

Petição mais de 500.000 eleitores................................................................................. + +4.00

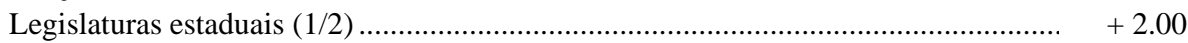

Convenções estaduais $(1 / 2)$.................................................................................. + +2.00

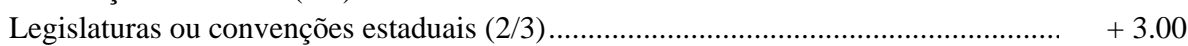

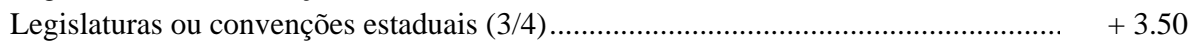

${ }^{35}$ LUTZ. Op. cit., p. 256.

${ }^{36}$ Ibid., pp. 254/260, Table 10. 
Órgão administrativo

$+0.50$

Órgão especificamente designado (1/3 ou menos) .................................................... + +0.25

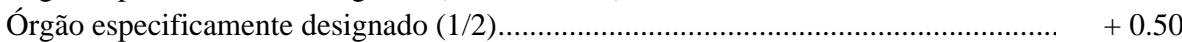

Órgão especificamente designado (maioria absoluta) ............................................. + 0.65

Órgão especificamente designado (3/5) .................................................................. + + 0.65

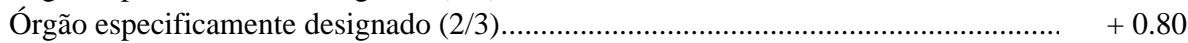

Órgão especificamente designado (3/4) .............................................................. + 0.90

(Qualquer um dos procedimentos acima em dois turnos) ...................................... +0.50

Legislatura Unicameral:

Maioria de $1 / 3$ ou menos ............................................................................... + 0.50

Maioria de $1 / 2$...................................................................................... + 0.50

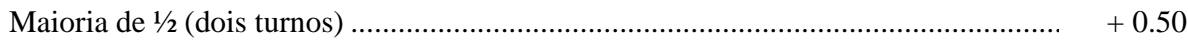

Maioria absoluta ............................................................................................. + +0.65

Maioria absoluta (dois turnos) ............................................................................ + 0.65

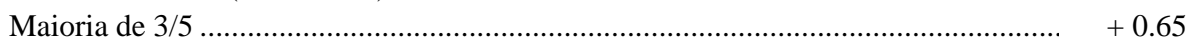

Maioria de 3/5 (dois turnos) ................................................................................ + 0.65

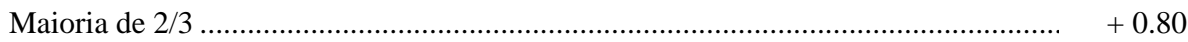

Maioria de $3 / 4$........................................................................................ + 0.90

Se uma eleição é requerida entre os turnos de votação............................................... + +0.25

Maioria de 2/3 (dois turnos) ............................................................................... + 1.75

Legislatura bicameral:

Maioria de $1 / 3$ ou menos ................................................................................... + 0.50

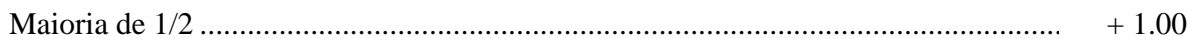

Maioria absoluta .......................................................................................... + 1.25

Maioria absoluta (dois turnos) ............................................................................ + 1.25

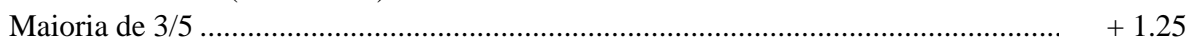

Maioria de $2 / 3$...................................................................................... +1.60

Maioria de $3 / 4$........................................................................................... +1.80

Maioria de 2/3 (dois turnos) .................................................................................. + 3.55

Se uma eleição é requerida entre os turnos de votação.............................................. + +0.50

Referendo $(1 / 2)$......................................................................................... + +1.50

Referendo (maioria absoluta) ..................................................................... +1.75

Referendo (2/3 ou mais) ............................................................................ + 2.00

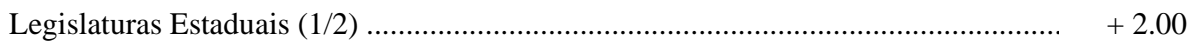

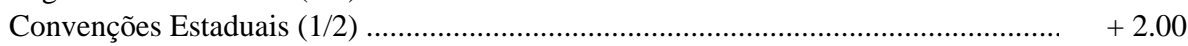

Legislaturas ou Convenções Estaduais $(2 / 3)$.......................................................... + +3.00

Legislaturas ou Convenções Estaduais (3/4) .......................................................... + +3.50

Maioria de eleitos e de Estados .............................................................................. + 3.75

Unanimidade de aprovação pelos governos estaduais .............................................. +4.00

Aplicando tais parâmetros à Constituição dos EUA, chega-se à seguinte conclusão: caso se adote o caminho que se inicia pelo Congresso, ter-se-á o índice de dificuldade de 5.10 (iniciativa de $2 / 3$ dos votos do Congresso (1.60) + ratificação por 3/4 de legislaturas convenções estaduais (3.50)); já se se utilizar o procedimento cuja 
deflagração compete às legislaturas estaduais, o índice será de 6.50 (iniciativa de 2/3 das legislaturas estaduais (2.25) + convenção nacional que delibera por maioria simples (0.75) + ratificação por 3/4 de legislaturas convenções estaduais (3.50)). ${ }^{37}$ A Constituição brasileira, por sua vez, apresenta três hipóteses distintas de iniciativa: se a iniciativa for de, no mínimo, um terço dos membros da Câmara dos Deputados ou do Senado Federal (art. 60, I, CRFB/1988), o índice será de 1.75 (iniciativa 0.50 + aprovação por 2/3 de Legislativo Bicameral em dois turnos (1.25)); se a iniciativa for do Presidente da República (art. 60, II, CRFB/1988), o índice será de 1.50 (iniciativa de órgão administrativo (0.25) + aprovação por 2/3 de Legislativo Bicameral em dois turnos (1.25)); se a iniciativa for de mais da metade das Assembléias Legislativas estaduais, o índice será de 3.25 (iniciativa de 1/2 das legislaturas estaduais (2.00) + aprovação por 2/3 de Legislativo Bicameral em dois turnos (1.25)).

Evidentemente que a circunstância de a base de dados do aludido quadro haver se restringido às cinqüenta Constituições estaduais dos EUA denota que os respectivos números não podem ser tomados senão como estimativas. Contudo, a sua aplicação fornece uma gama considerável de critérios que, através das suas combinações, abrange boa parte dos processos de reforma, bem como evidencia, com razoável precisão, o correspondente nível de rigidez, como, aliás, se infere do cotejo entre os processos de alteração formal das Constituições norte-americana e brasileira.

De fato, a sua aplicação revela que os processos mais rígidos são precisamente os menos manejados - v.g.: no caso dos EUA e do Brasil os procedimentos de iniciativa das legislaturas estaduais -, bem como que a maior dificuldade do processo de emenda à Constituição dos EUA, sobretudo quando comparado ao brasileiro, constitui razão de peso para, dentre outras circunstâncias, justificar a enorme distância existente entre os índices de emendabilidade nos EUA e no Brasil (respectivamente: 0.12, ante a aprovação de vinte e seis emendas ${ }^{38}$ em duzentos e dezoito anos; 3.10, já que foram editadas sessenta e duas emendas em vinte anos, incluídas as de revisão).

Convém ser feito, porém, um esclarecimento. Não se pretende aferir, em definitivo, o grau de rigidez constitucional de um regime concreto apenas mediante a aplicação dos referidos parâmetros aos dispositivos que disciplinam o processo de reforma constitucional. Em outras palavras, a questão não se resume à singeleza de uma operação matemática feita a partir do direito constitucional positivo. A bem da verdade, cumpre promover uma aferição empírica a respeito da viabilidade de as instituições

\footnotetext{
${ }^{37} \mathrm{O}$ segundo procedimento nunca foi utilizado. A propósito, o art. V da Constituição dos EUA assim dispõe: “A maioria representada por dois terços dos membros de ambas as Câmaras, poderá, se julgar necessário, propor emendas a esta Constituição ou, por requerimento das legislaturas de dois terços dos Estados, convocar uma Convenção encarregada de propor emendas; em todas essas hipóteses, as emendas se tornarão parte integrante desta Constituição, após a sua ratificação pelas legislaturas ou por convenções em três quartos dos Estados, livre o Congresso para propor uma ou outra dessas formas de ratificação. (...)”.

${ }^{38}$ Não se abordará aqui a celeuma relativa à incorporação ou não da chamada décima sétima emenda à Constituição dos EUA, dado o longo lapso de tempo para a sua ratificação pelos Estados-Membros. V. LEVINSON, Sanford. "How Many Times Has the United States Constitution Been Amended? (A) < 26; (B) 26, (C) 27; (D) > 27." In: LEVINSON, Sanford. Responding to Imperfection - The Theory and Practice of Constitutional Amendment, Princeton: Princeton University Press, 1995; TRIBE, Laurence. "The $27^{\text {th }}$ Amendment Joins The Constitution”. In:Wall Street Journal, May, 13, 1992.
} 
competentes para a alteração formal da constituição atingirem, efetivamente, as supermaiorias necessárias a tal desiderato.

Este ponto pode ser ilustrado pela comparação entre as experiências francesa e brasileira. Cotejando-se o art. 89 da Constituição da Quinta República Francesa, editada em 1958 no governo de Gaulle, com o art. 60, da Constituição Brasileira de 1988, constata-se que os processos de reforma constitucional a cargo do Parlamento estão sujeitos a rigores procedimentais relativamente próximos (apreciação por ambas as Casas Legislativas pelo quorum de três quintos, sendo que o modelo brasileiro exige ainda dois turnos de votação). ${ }^{39} \mathrm{Na}$ França, tendo em vista o Senado representar, fundamentalmente, as populações rurais mais conservadoras, tal instituição se revela avessa a mudanças, exercendo o seu poder de veto para bloquear projetos de emenda constitucional, em especial aqueles de caráter mais progressista. Esta circunstância, somada às divisões existentes entre os principais partidos políticos e mesmo no âmbito interno de cada um deles, evidencia a dificuldade de atingir-se na França a supermaioria parlamentar necessária à aprovação de reformas constitucionais. ${ }^{40}$

Como corolário, segundo o levantamento feito por Guy Carcassone, foram aprovadas somente oito emendas constitucionais no período entre 1958 e 1994, a maioria delas referentes a questões de relevância e de conflituosidade política reduzidas. Tais fatores políticos revelam que, se, por um lado, a rigidez da Constituição da Quinta República trouxe à França uma estabilidade política há muito desejada, fixando regras do jogo democrático imunes a mudanças de governo, por outro, talvez se verifique um nível ligeiramente acentuado de rigidez que somente permite alterações significativas na constituição pelo processo alternativo de convocação direta de um referendo pelo Presidente da República. ${ }^{41}$

Voltando os nossos olhos à realidade brasileira, constata-se que, embora o processo seja formalmente mais difícil - dada a exigência de dois turnos de votação em ambas as Casas -, na prática os governos de ocasião não vêm encontrando obstáculos de difícil transposição à alteração formal da constituição. Muito pelo contrário, a circunstância de haverem sido aprovadas cinqüenta e seis emendas constitucionais (excluídas as de revisão) em vinte anos revela que os governos têm logrado superar,

${ }^{39}$ A propósito das emendas à Constituição da Quinta República Francesa, Guy Carcassone afirma que "In terms of legal theory, the way to amend the Constitution is set out in article 89. According to this, the initiative for an amendment may come either from the president, upon a proposition made by the prime minister, or from any member of parliament. If the draft bill is put on the agenda, which only occurs when the initiative comes from the president, each chamber must adopt it in the same form. When this is done, the bill must still be ratified by referendum, unless the president chooses to submit it to the Congress, which must ratify it by a qualified majority of three-fifths." Em seguida esclarece que "according to art. 89, when the president is the initiator of the procedure, he may choose either Congress or a referendum. On the contrary, when the initiative comes from the parliament (which has never happened so far) the only method of ratification is by referendum”. Há ainda uma espécie de atalho para se alterar a Constituição Francesa de 1958: a convocação direta pelo Presidente do referendo previsto no art. 11, caminho seguido por De Gaulle em 1962 para a introdução da eleição direta para Presidente da República. V. CARCASSONE, Guy Constitutional Change in France. In: Constitutional Policy and Change in Europe. HESSE, Joachim Jens; JOHNSON, Nevil (org.). Oxford: Oxford University Press, 1995, pp. 166, 167 e 177.

${ }^{40}$ V. CARCASSONE, Guy.Ibid.

${ }^{41}$ Ibid. Para a compreensão deste atalho, v. supra (nota ${ }^{\circ}$ 36). 
com uma freqüência quiçá indesejável, os requisitos procedimentais pertinentes ao processo de reforma - ainda que, infelizmente, em algumas ocasiões haja suspeitas do emprego de métodos obscuros, como nos revela a crise do chamado "mensalão".

3.3 É possível relacionar as características gerais do texto constitucional com o grau de dificuldade do respectivo processo de reforma?

Parece-nos que a conclusão acerca do nível de rigidez de um regime constitucional concreto pressupõe que se associe o nível de dificuldade do procedimento de reforma com outros fatores. Já se destacou acima que os graus de extensão, abrangência e detalhamento do texto constitucional contribuem para a aferição do nível de rigidez. Desta forma, associando-se tais critérios com o nível de dificuldade do processo de reforma, é lícito asseverar, por exemplo, que um regime político cuja constituição se perca em miudezas, apresentando caráter casuístico e prolixo, e que preveja processo de reforma bastante dificultoso, apresenta sérios riscos à prevalência do ideal de autogoverno popular no respectivo país. Com efeito, a retirada de uma enorme gama de matérias do poder deliberativo das gerações supervenientes à constituinte cristalizando-se, eventualmente, privilégios -, representaria um fortíssimo "engessamento da constituição”, porquanto as gerações pós-constituintes achar-se-iam vinculadas a um projeto específico de desenvolvimento da sociedade que não é de sua autoria.

Assim, o altíssimo nível de rigidez constitucional, traduzido num baixo índice de emendabilidade, acabará conduzindo o povo a, com pálio no seu inequívoco direito de viver segundo as normas estatuídas pela sua geração e não por seus antepassados, promover uma ruptura institucional, ou pior, a descumprir sistematicamente a constituição, cuja força normativa seria progressivamente erodida. Tais considerações confluem com a proposição (iv), no que se refere à circunstância de que, quanto menor for o índice de emendabilidade, maior a probabilidade de substituição da ordem constitucional.

Por outro lado, caso à excessiva abrangência, extensão e detalhamento do texto constitucional se vincule processo de emenda relativamente "fácil", este fator irá temperar a rigidez ocasionada por aquele, correndo-se, entretanto, risco (reconheça-se, não tão intenso) de ruptura institucional. Explica-se: se o casuísmo do texto constitucional implicará, igualmente, a necessidade de mudança, neste caso, porém, a alteração formal da constituição não estará obstaculizada por um processo excessivamente rigoroso.

Há aqui fundado receio de ter-se um índice de emendabilidade alto, e, com o passar do tempo, um texto constitucional desfigurado. Neste viés, a proposição (iv) também ressalta que, quanto maior o índice de emendabilidade, maior será a probabilidade de ruptura total, tendo em vista a conveniência de uma constituição que se transformou numa "colcha de retalhos" ser substituída por um texto coerente. Ainda que não ocorra a substituição total da constituição, a freqüente alteração do texto constitucional gera instabilidade política e dificilmente suscita um sentimento constitucional, olvidando-se de que a constituição não é apenas norma a ser obedecida, mas também um símbolo a ser cultivado pelo povo, algo que, todavia, pressupõe um estado de deferência generalizada aos seus ditames que só se consolida com o tempo.

Corolário natural do exposto é a proposição (vii). Isto porque, o alto índice de 
emendabilidade, decorrente da forte densidade normativa da constituição e da sua sujeição a processo de reforma não tão dificultoso, não gera apenas risco de ruptura institucional, mas também esmaece as fronteiras entre a normativa constitucional e a legislação comum, como que "ordinarizando" a constituição, visto que, em boa medida, furta a sua especial dignidade normativa. A extensão do texto constitucional e a relativa facilidade dos órgãos do Estado em alterá-lo contribuirão, portanto, para que sejam inseridas na constituição normas que correspondem à vontade política do momento. Desvia-se, então, a constituição do seu papel de estabelecer as regras do jogo político e a tutela de elementos constitucionais essenciais (i.e.: direitos fundamentais), para uma subalterna função de instrumento de ação política, manejado com vistas a retirar do alcance de maiorias futuras doutrinas abrangentes e particulares, ou mesmo privilégios, de grupos que possuam força política suficiente para a promoção de alterações constitucionais com o escopo de cristalizar os seus interesses.

Embora a Constituição de 1988 haja gozado de força normativa sem precedentes no constitucionalismo pátrio, e, repise-se, apesar de o processo constituinte possuir em média maior qualidade deliberativa do que o constituinte reformador e o legislativo ordinário, o seu caráter casuístico e prolixo, evidenciado pelos duzentos e cinqüenta artigos integrados ao seu corpo permanente, e pelos noventa e quatro artigos do ADCT, além da aprovação de sessenta e duas emendas constitucionais num período de vinte anos, atingindo-se um elevado índice de emendabilidade (3.10), deixa claro que a Carta de 1988 se sujeita aos riscos antes alvitrados. Exemplo paradigmático do exposto pode ser extraído da Emenda Constitucional $n^{0}$ 51, de 14 de fevereiro de 1996, que, no parágrafo único do seu artigo segundo, convalidou o provimento de agentes comunitários de saúde e agentes de controle de endemias que ingressaram no serviço público sem o cumprimento da regra constitucional da obrigatoriedade de concurso público (art. 37, II, CF/88).

Parece evidente que uma tal “ordinarização” da constituição reduz bastante o espaço de livre conformação legislativa, na medida em que a implementação de um novo plano de governo pressupõe que os vencedores do pleito formem uma coalização ampla o suficiente para garantir-lhes a supermaioria de três quintos necessária à alteração da constituição. Há, assim, uma confusão entre as políticas constituinte e ordinária, que faz com que, não-raro, emendas constitucionais tenham que ser aprovadas para a adoção de reformas previdenciárias, administrativas, tributárias, etc, que melhor estariam disciplinadas em normas infraconstitucionais. Tais emendas constitucionais mais se assemelham a leis complementares, verificando-se no Brasil uma elevação de patamar no âmbito da debate institucional que se verifica entre o Judiciário e os poderes democraticamente legitimados: enquanto na grande maioria dos países cumpre ao Judiciário realizar o cotejo entre lei e norma constitucional, aqui se afigura freqüente o contraste entre emenda e cláusula pétrea. Tal circunstância revela uma dose sensível de rigidez do nosso regime constitucional, pois, para além de permitir o controle da constitucionalidade de emendas pelo Judiciário, sujeita a alteração de uma série de questões do dia-a-dia da política a uma maioria qualificada, viabilizando que uma minoria obstaculize a prevalência da vontade da maioria num dado momento histórico. 
Assim, parece pertinente que o constituinte derivado "desconstitucionalize" matérias despidas de especial dignidade normativa (excluídos, entre outras normas, os direitos fundamentais de primeira, segunda e terceira geração), com vistas a preservar um espaço razoável para o pluralismo político. Ademais, deve o Judiciário adotar uma postura mais ativa do que a habitual na tutela da constitucionalidade de emendas constitucionais veiculadoras de privilégios (v. exemplo supra), e, inversamente, adotar forte dose de judicial self restraint quando for suscitada a inconstitucionalidade de determinado ato normativo que restrinja cláusulas constitucionais deste jaez. ${ }^{42}$

A par disto, convém destacar que um texto constitucional de baixa densidade normativa, em virtude, i.e., do seu caráter sintético e fluido, implica, prima facie, restrição menos intensa à democracia. Isto porque, de um texto constitucional sintético se infere a retirada de uma quantidade reduzida de matérias do alcance do processo deliberativo ordinário, enquanto da sua fluidez - derivada, p. ex., da prevalência de normas-princípio sobre normas-regra -, decorre, prima facie, um maior espaço de livre conformação do legislador na concretização da constituição. ${ }^{43}$ Combinadas tais características com um procedimento de reforma relativamente fácil, ter-se-á, a princípio, uma constituição com baixo nível de rigidez, pois, ao amplo espectro de atuação do legislador ordinário se somará um caminho não menos largo de alteração formal da constituição (processo que, não-raro, é dominado pelas legislaturas). Privilegia-se, pois, o pluralismo político e a adaptabilidade do projeto constitucional aos consensos constitucionais e à sua permanência.

Interessa-nos, por fim, vislumbrar hipótese em que se associe a baixa densidade normativa da constituição a processo de reforma bem rigoroso. Este é o caso, por exemplo, da Constituição dos EUA, cujo corpo permanente conta com apenas sete artigos e cujos rigores do processo de reforma previsto no seu art. V conduziram a elevados índices de dificuldade: 5.10 ou 6.50, de acordo com a sua iniciativa. ${ }^{44}$ Neste caso, a conseqüência natural é a apresentação de baixo índice de emendabilidade (in casu 0.12) decorrente da aprovação de apenas vinte e seis emendas em duzentos e vinte e um anos de vigência da Carta.

Resta indagar se, e, em caso positivo, de que modo, a identificação da teoria de interpretação constitucional prevalecente no seio da Suprema Corte contribui para o aprofundamento da análise empreendida no presente projeto.

3.4. Pode-se estabelecer um vínculo entre o grau de dificuldade do processo de reforma e o caráter mais ou menos "construtivista” da teoria de hermenêutica constitucional prevalecente no seio da Suprema Corte?

Diante da necessidade de serem realizadas mudanças, com o escopo de adaptar a constituição à realidade superveniente, afigura-se consectário da associação de um

\footnotetext{
42 A propósito das restrições legislativas a normas constitucionais, ver BARCELLOS, Ana Paula de. Ponderação, Racionalidade e Atividade Jurisdicional. Rio de Janeiro: Renovar, 2005; PEREIRA, Jane Reis Gonçalves. Interpretação Constitucional e Direitos Fundamentais. Rio de Janeiro: Renovar, 2006.

${ }^{43}$ Cumpre repisar o caráter prima facie desta assertiva, tendo em vista que a eventual adoção de uma teoria de interpretação constitucional construtivista - a qual se afigura possível ante a abertura do texto constitucional -, tende a comprimir o âmbito de atuação do Parlamento, circunstância que restringe o princípio democrático. ${ }^{44} \mathrm{~V}$. supra.
} 
baixo índice de alteração formal com a longa duração da constituição, a intensa utilização de métodos informais de reforma constitucional em detrimento dos formais, especialmente através da mutação constitucional. Em tal mecanismo informal há, normalmente, uma primazia do Judiciário (proposição v), enquanto o processo de alteração formal da tende a ser dominado pelos “poderes” legitimados pelo voto, especialmente pelo Legislativo.

Isto porque, fixado o caráter normativo da constituição e, por conseguinte, afastada a hipótese de a normativa constitucional haver se restringido a um repositório ineficaz de exortações ao legislador, as mudanças ocorridas no âmbito da realidade devem se refletir no âmbito da constituição. Se assim é, um índice baixo de emendas/ano revela que estas inevitáveis alterações não estão sendo veiculadas pela via formalmente instituída para este propósito (emendas constitucionais), mas mediante o emprego de métodos informais.

Ora, se há uma intuitiva relação de inversa proporcionalidade entre o grau de dificuldade do processo de reforma e o índice de emendabilidade de um sistema constitucional, na medida em que, quanto mais rigoroso for o processo de emenda à constituição, menos emendas tenderão a ser aprovadas por ano, parece lícito concluir que, quanto mais difícil for o processo de alteração formal da constituição, maior será a importância dos mecanismos informais de reforma, diante da inevitabilidade de as mudanças fáticas se reproduzirem no seio de constituições normativas (proposições v e vi).

Prosseguindo no raciocínio, se um maior rigor no processo de emenda abre espaço mais amplo para a mutação constitucional, e se o Judiciário costuma ter primazia no manejo deste mecanismo, pode-se concluir que, na hipótese de se verificar um processo difícil de emenda à constituição, se afigura pouco provável de o Judiciário se valer de métodos de interpretação constitucional que o sujeitem a limites mais estreitos, pois tais métodos o tolheriam de proceder à atualização da constituição na extensão que se faz necessária ante a obstaculização do mecanismo institucionalizado para tanto. É mais provável, ao revés, que adote concepções, por assim dizer, construtivistas (proposição viii).

Pelas mesmas razões, a proposição de número oito também adverte para a hipótese inversa: quanto mais “fácil” for o processo de alteração formal, maior a propensão de o Judiciário adotar teoria mais autorestritiva de interpretação constitucional, visto que haverá maior tendência de os órgãos responsáveis pela aprovação de emendas à constituição utilizarem-nas em detrimento da alteração informal da constituição por obra do Judiciário. Se, na vertente hipótese, o espaço para o Judiciário proceder à mutação constitucional se revela reduzido, é, de fato, mais provável que empregue teorias de interpretação constitucional menos construtivistas.

De qualquer sorte, há nítida tendência no estabelecimento de uma relação de direta proporcionalidade entre o rigor do processo de alteração formal e o grau de “ativismo judicial” na atualização da constituição, é dizer: quanto mais difícil for o processo de alteração formal, maior o espaço para a mutação constitucional por obra do Judiciário, e, conseqüentemente, mais construtivista deverá ser a teoria constitucional 
empregada pela Corte Constitucional. Apesar desta ilação ser intuitiva e ter sido extraída do exame da aplicação das cinqüenta constituições estaduais dos EUA, há aqui um amplo espaço para pesquisas empíricas baseadas numa análise interdisciplinar e comparativa entre as dificuldades enfrentadas, efetivamente, pelas coalizões governamentais aprovarem mudanças e o grau de ativismo judicial na atualização da constituição.

De qualquer forma, devem ser construídos parâmetros aptos a distinguir as mudanças constitucionais que só podem ser veiculadas por emenda constitucional, em face daquelas viáveis de implementação por decisão judicial.

4. OS CAMINHOS PARA A ALTERAÇÃO DA CONSTITUIÇÃO: DECISÕES JUDICIAIS VERSUS EMENDAS CONSTITUCIONAIS

4.1 É viável distinguir as mudanças constitucionais suscetíveis de implementação por interpretação judicial daquelas que só podem ser veiculadas por Emenda Constitucional?

Trata-se de questão que é objeto de profícuo debate nos meios acadêmicos norte-americanos, muito embora se verifique uma abordagem rarefeita na doutrina pátria, especialmente em virtude da falta de uma análise relacional acerca dos limites e possibilidades da atualização da constituição pelo Judiciário e por emenda constitucional. À vista disto, buscar-se-á destacar as principais concepções a respeito da matéria na América, analisando-se, em seguida, em que medida tais aportes revelam-se aplicáveis à nossa realidade.

Preliminarmente, convém trazer à baila uma indagação: quantas vezes a Constituição de 1988 foi “alterada”?

Uma primeira aproximação da questão se apega a um critério formal, e conduz à seguinte resposta: sessenta e duas, tendo em vista a aprovação de cinqüenta e seis emendas constitucionais, além das seis de revisão. Entretanto, tal perspectiva implica um empobrecimento teórico da questão, pois identifica a constituição com o seu texto. ${ }^{45}$ A constituição material, ou o corpus constitucional, no dizer de Canotilho, abrange, além dos seus dispositivos, os costumes constitucionais, institutos cuja disciplina foi reenviada pelo constituinte à lei, e as interpretações constitucionais da lavra do Judiciário. ${ }^{46}$

Especial destaque deve ser conferido às últimas, eis que a retirada de matérias do alcance do legislador ordinário se verifica, corriqueiramente, não apenas pela sua expressa inclusão na constituição, mas também pela sua “constitucionalização” mediante precedentes judiciais concebidos no âmbito do exercício do controle da constitucionalidade das leis. Do exposto, parece lícito concluir que a constituição material pode ser alterada tanto por emenda constitucional quanto por decisão judicial. Cumpre-nos, portanto, distinguir as modificações que podem ser implementadas pelo Judiciário daquelas que só são admitidas pela via das emendas.

\footnotetext{
${ }^{45}$ LEVINSON, Sanford. Op. cit., p. 26.

${ }^{46}$ CANOTILHO, José Joaquim Gomes. Op. cit., , p. 1133 e seq.
} 
Um primeiro critério seria o da relevância: as alterações mais importantes, incidentes sobre questões materialmente constitucionais, sujeitar-se-iam exclusivamente às emendas. Tal proposição, contudo, esbarra na dificuldade de serem identificadas tais questões, especialmente em virtude da profusão de teorias de interpretação constitucional. ${ }^{47}$ Além disto, a suposta exclusividade das emendas constitucionais para a veiculação de alterações constitucionais substanciais contrasta com uma análise empírica consistente do papel que elas vêm desempenhando no constitucionalismo comparado. Nesse viés, Vile salienta que as emendas, para além de promoverem alterações constitucionais, cumprem também as funções de iniciar, sancionar, impedir ou reverter mudanças, ou mesmo de consolidar o status quo. Idênticas funções, por sua vez, são desempenhadas por decisões judiciais, ${ }^{48}$ circunstância que evidencia que qualquer distinção calcada num elemento funcional está fadada ao insucesso.

Com lastro em percuciente exame da história constitucional americana, notadamente de três momentos paradigmáticos, quais sejam a Fundação, o período pós Guerra Civil e o New Deal, Ackerman salienta que as alterações constitucionais mais significativas não tendem a coincidir com a aprovação de emendas constitucionais. Ao contrário, os referidos momentos constitucionais, assim entendidos os períodos de excepcional mobilização cívica de uma Nação nos quais os seus líderes políticos adquirem legitimidade para deliberarem em nome do povo, revelam um processo político e social muito mais complexo do que se pode depreender de uma análise legalista do procedimento de reforma constitucional.

Em abreviada síntese, Ackerman entende cuidar-se de processo composto por quatro etapas, assim sucessivamente dispostas: (i) impasse constitucional, no qual os principais atores políticos contendem, em termos relativamente iguais, a respeito de determinada matéria de relevo constitucional; (ii) batalha eleitoral, na qual lutam pelo apoio popular à sua respectiva tese. Caso não se verifique uma vitória inquestionável, é de se esperar que os perdedores questionem o apoio popular conferido à tese constitucional dos vencedores, mostrando-se céticos acerca destes representarem a vontade constituinte do povo. Pode ser, então, o caso de inaugurar o terceiro estágio, (iii) que consiste na objeção formulada pelo "poder vencedor" em face da independência institucional dos "poderes vencidos”. Estes devem, então, tomar uma decisão difícil: manter a batalha e aguardar as novas eleições, sujeitando-se aos evidentes riscos de instabilidade institucional, ou aceitar a derrota e, via de conseqüência, a nova ordem constitucional. O estágio final (iv) consiste, precisamente, na mudança de posição dos derrotados, firmes na convicção de que a insistência na querela conduziria apenas à destruição institucional. ${ }^{49}$

\footnotetext{
${ }^{47}$ A propósito dos mais conhecidos métodos de interpretação constitucional, conferir CANOTILHO, J. J. Gomes. Op. cit., 1195 e ss..

${ }^{48}$ VILE, John. R. Constitutional Change in the United States - A comparative study of the role of constitutional amendments, judicial interpretations, and legislative and executive actions. Connecticut: Praeger, 1994, pp. 16 e 35.

${ }^{49}$ ACKERMAN, Bruce. Higher Lawmaking. In: LEVINSON, Sanford. Responding to Imperfection The Theory and Practice of Constitutional Amendment, Princeton: Princeton University Press, 1995, pp. $78 / 79$.
} 
A tese do Professor de Yale agrega importantes elementos ao debate. Preliminarmente, afasta a assertiva, tão disseminada entre os juristas, de que as emendas constitucionais representam o único instrumento de alteração "legal” da constituição. Ademais, contempla as múltiplas funções desempenhas pelas emendas já salientadas por Vile, e evidencia que a temática das alterações constitucionais tem um colorido político que não deve ser olvidado por análises legalistas acerca dos seus limites e possibilidades.

Entretanto, a lição mais importante deixada por Ackerman ao direito brasileiro parece ser a pertinência da aplicação da premissa da democracia dualista à compreensão do papel das emendas constitucionais em nosso sistema constitucional, algo que, por questões didáticas, será abordado no subseqüente item. Nada obstante, a teoria de Ackerman não pode ser implementada, na sua inteireza, no constitucionalismo brasileiro. Isto porque, embora a colocação das emendas constitucionais na periferia do processo de modificação constitucional se revele plausível no contexto de uma constituição sintética como a norte-americana, que conviveu com modificações radicais ao longo dos seus dois séculos de vigência sem alteração do seu texto (cujo exemplo maior é o New Deal), o mesmo não se pode dizer no contexto brasileiro. No âmbito de uma constituição abrangente, detalhista e densa, como a brasileira de 1988, parece evidente que o espaço para a sua alteração por decisão judicial é menor.

Chega-se, então, a um ponto fundamental no esforço para a construção de uma resposta adequada à questão antes formulada: a atualização da constituição pelo Judiciário se consubstancia em atividade interpretativa. Com isso não se quer dizer que o juiz atue simplesmente como a "boca da lei", pois lhe cumpriria uma atividade mecânica de revelação do sentido preestabelecido pelo legislador constituinte, segundo um raciocínio silogístico típico de teses convencionalistas. ${ }^{50}$ Ao contrário, tal assertiva revela que a criatividade judicial na atualização da constituição restringe-se ao âmbito de livre conformação demarcado pelos limites semânticos do texto constitucional. Trata-se de corolário da submissão dos três “poderes”, inclusive e notadamente do Judiciário, à constituição.

Desta feita, não se pode admitir a prolação pelo Judiciário de "interpretações contra o texto da constituição”, pois já não se cuidaria de atividade interpretativa, mas verdadeiramente modificativa do dispositivo "interpretado". ${ }^{51}$ Este desvio pode

\footnotetext{
${ }^{50}$ V. LA TORRE, Massimo. Theories of Legal Argumentation and Concepts of Law. An Approximation. Ratio Iuris. Vol. 15, $\mathrm{n}^{\circ}$ 4. December, 2002, pp. 377-402; DWORKIN, Ronald. Law's Empire. London: Duckworth, 1986, v. capítulo três.

${ }^{51}$ Também em virtude de a literalidade da constituição demarcar o espaço de criatividade judicial, parece correta a tese que se restringe a reconhecer as mutações constitucionais propriamente ditas, em cujo âmbito as autoridades responsáveis pela interpretação da constituição atualizam os seus dispositivos à realidade fática superveniente, atuando dentro dos limites semânticos do dispositivo constitucional objeto da interpretação. Deve-se, portanto, negar a legitimidade das chamadas mutações inconstitucionais, nas quais as interpretações legislativa, judicial e administrativa contrariam a letra ou princípios estruturais da constituição, ou se consolidam práticas e costumes contra constitutionem. Segue-se, pois, o magistério de Canotilho, para quem tais mutações não podem ser admitidas, sob pena de tolerar-se a "existência de uma realidade constitucional inconstitucional, ou seja, alterações manifestamente incomportáveis pelo programa da norma constitucional.” CANOTILHO. Op. cit., p. 237.
} 
se revelar através da real vontade de alterar a constituição e não de interpretá-la de boa-fé, ou da manifesta inconsistência da fundamentação de determina diretriz como interpretação, mais parecendo uma tentativa sub-reptícia de emenda à constituição. ${ }^{52}$ A possibilidade de o Judiciário alterar a interpretação de um dispositivo constitucional, sem que haja modificação do seu texto, mas tão-somente em virtude da alteração da realidade fática que lhe é subjacente (mutação constitucional), situa-se, portanto, dentro dos limites semânticos do texto constitucional.

Daí porque, embora a dificuldade do processo de reforma estimule um maior ativismo na atualização judicial da Constituição, ${ }^{53}$ um limite imposto a tal mister no seio de constituições normativas é a abertura do texto constitucional. Assim, uma constituição de caráter eminentemente principiológico confere, prima facie, maior espaço à mutação constitucional do que um documento composto, basicamente, por regras. $^{54}$

Confira-se um exemplo óbvio do que se expôs: a Emenda Constitucional n 50/2006 alterou o período das duas sessões legislativas ordinárias anuais estabelecidas no art. 57 caput. Tendo em vista que os respectivos lapsos temporais foram previstos de forma expressa na Constituição de 1988, parece evidente que apenas uma emenda constitucional, nunca uma decisão judicial ou um ato interno do Parlamento, poderia alterá-los, como de fato ocorreu.

Apesar da singeleza do exemplo dado, a questão em análise, antes de restringir-se a uma mera tecnicalidade jurídica, apresenta implicações políticas de relevo, sobretudo no que tange à extensão das competências do Legislativo e do Judiciário interpretarem e desenvolverem a constituição, ponto que se revela sensível para a separação harmônica dos poderes no âmbito de uma democracia representativa. O caso - bem mais complexo - da suposta mutação constitucional do art. 52, X, da Constituição de 1988 ilustra o que se vem de expor.

O referido dispositivo cuida da possibilidade de o Senado Federal suspender a eficácia de lei declarada inconstitucional pelo STF. Tal competência fora conferida originalmente ao Senado pela Constituição de $1934^{55}$ e tinha por escopo atribuir efeitos erga omnes a decisões proferidas pelo Supremo Tribunal no controle incidental de constitucionalidade, que, na esteira de iterativa doutrina e jurisprudência pátrias, apenas produzem efeitos inter partes. ${ }^{56}$ Buscava-se, portanto, estender os efeitos da

${ }^{52}$ LEVINSON, Sanford. "How Many Times Has the United States Constitution Been Amended? (A) <26; (B) 26; (c) 27; (d) > 27: Accounting for Constitutional Change". In: LEVINSON, Sanford. Responding to Imperfection - The Theory and Practice of Constitutional Amendment, Princeton: Princeton University Press, 1995, p. 17.

${ }^{53}$ V. LUTZ, Donald. Op. cit.

${ }^{54}$ V. item 3.1. Dados os limites do presente estudo, não será analisada a possibilidade de superação de regras, a qual se revela especialmente problemática se a regra em questão tiver estatura constitucional. Sobre o tema, conferir ÁVILA, Humberto Bergman. Teoria dos Princípios - da definição à aplicação dos princípios jurídicos. 5 ed. São Paulo: Malheiros Editores, 2006.

55 Tal competência fora originalmente positivada no art. 91, IV, da Constituição de 1934, e, posteriormente, reiterada nos arts. 65 da Constituição de 1946, 42, VII, da Constituição de 1967, e 52, X, da Constituição de 1988.

${ }^{56}$ V. CLÉVE, Clemerson Merlin. A Fiscalização Abstrata da Constitucionalidade no Direito Brasileiro. 2 ed. São Paula: Editora Revista dos Tribunais, 2000. 
declaração incidental da inconstitucionalidade de uma lei a casos substancialmente idênticos, mas cujas partes fossem distintas, minimizando os malefícios causados à segurança jurídica e à isonomia, decorrentes da importação pela Constituição de 1891 do modelo norte-americano de controle de constitucionalidade sem a doutrina do stare decisis.

O Ministro Gilmar Mendes, porém, considera que o art. 52, X, da Constituição sofreu uma mutação constitucional, na medida em que, apesar de o seu texto permanecer incólume, a mudança dos contextos fático e normativo que o circundam conduziria à conclusão de que, atualmente, o mencionado dispositivo destina-se apenas a autorizar que o Senado edite resolução que confira maior publicidade às decisões do STF em controle incidental de constitucionalidade. Isto porque tais acórdãos, assim como os proferidos em controle abstrato, produziriam per se efeitos subjetivos erga omnes e não apenas inter partes, em oposição ao que afirmam doutrinadores e juízes, praticamente em uníssono, há mais de um século. ${ }^{57}$

A concessão de efeitos erga omnes às decisões proferidas pelo STF em controle incidental de constitucionalidade, embora conveniente sob o prisma da política judiciária, parece-nos juridicamente impossível pela via da interpretação judicial construtiva. Com efeito, caso o autor deste artigo fosse membro do Congresso Nacional seria simpático a projeto de emenda constitucional que introduzisse tal inovação, eis que poria termo à possibilidade de juízes e Tribunais refazerem livremente o juízo do STF a respeito da constitucionalidade de uma lei, impedindo que o órgão de cúpula do Poder Judiciário exerça, plenamente, a sua função de uniformizar a jurisprudência constitucional no país. ${ }^{58}$ Imagine-se a seguinte situação: instala-se no Judiciário brasileiro forte controvérsia a respeito da constitucionalidade de uma lei previdenciária

\footnotetext{
${ }^{57}$ Embora não caiba aqui mais do que uma breve menção aos fundamentos desta inovadora tese, o emérito constitucionalista alude aos seguintes fatores: (i) o fato de tal competência ter sido prevista em favor do Senado numa época em que a concessão de efeitos erga omnes às decisões do STF era vista como atentatória à separação dos poderes; (ii) o avanço do método abstrato de controle de constitucionalidade em detrimento do incidental (e conseqüentemente das decisões do STF com efeitos erga omnes sobre aquelas com efeitos inter partes); (iii) a natureza idêntica dos mencionados métodos quanto às suas finalidades e procedimentos (proteção da supremacia da constituição e quorum de maioria absoluta); (iv) o aumento do número de decisões judiciais dotadas de efeitos erga omnes (ação civil pública e ação popular, onde inclusive se admite o controle incidental); (v) o atual volume de processos submetidos ao STF, muitos rigorosamente idênticos; (vi) e a criação no direito positivo, com inspiração em jurisprudência do STF, de instrumentos de vinculação dos Tribunais às decisões do STF em controle incidental, como p. ex., os arts. 481, p. único, e 557, p. 1-A, do CPC, etc.

${ }^{58}$ Calha mencionar a advertência de James Bradley Thayer, formulada em artigo clássico publicado na Harvard Law Review de 1893, que tanto influenciou a doutrina da autorestrição judicial (judicial selfrestraint), ao delinear, de forma reduzida, o escopo do controle de constitucionalidade das leis, notadamente no que toca à preservação de todas as escolhas legislativas dotadas de racionalidade, nas hipóteses em que a constituição admitir diferentes interpretações. A propósito, salienta Thayer: "the meaning and the effect of it are shortly and very strikingly intimated by a remark of Judge Thomas Cooley, to the effect that one who is a member of a legislature may vote against a measure as being, in his judgment, unconstitutional; and, being subsequently placed on the bench, when this measure, having been passed by the legislature despite of his opposition, comes fore him judicially, may there find it his duty, although he has in no degree changed his opinion, to declare it constitutional ...”. THAYER, James Bradley. The origin and the scope of the American doctrine of constitutional law. Harvard Law Review 129 (1893), p. 606, em cuja epígrafe consta a seguinte frase: “Qualquer escolha que seja racional é constitucional”.
} 
que atinge dezenas de milhares de aposentados e pensionistas. Uma década depois a questão chega ao STF, que finalmente dirime a controvérsia. Pergunta-se: é razoável, mediante uma interpretação elastecida dos princípios do juiz natural e do livre convencimento do juiz, autorizar que o juiz refaça o juízo de constitucionalidade formulado pelo STF? Parece evidente que não. Ao contrário, a vinculação do juiz a decisão do STF prestigia os princípios da isonomia e da segurança jurídica, na medida em que garante a igualdade de tratamento entre casos iguais e uma previsibilidade mínima da conduta prescrita pelo direito.

Tais razões, entretanto, não conduzem à conclusão exposta pelo Ministro Gilmar Mendes. A introdução da súmula vinculante pelo art. 103-A da Constituição Federal, com a redação que lhe foi dada pela $\mathrm{EC} \mathrm{n}^{\circ} 45$, parece confirmar essa tese. Isto porque, qual seria a serventia em aprovar-se uma súmula dotada de efeito vinculante se as decisões em geral do STF em controle incidental já possuíssem essa eficácia especial? A circunstância de as súmulas vinculantes terem seu objeto restrito à "matéria constitucional” conduz à conclusão de que a concessão de efeito vinculante a toda e qualquer decisão que veicule controle incidental esvaziaria o seu objeto e o seu escopo. E mais: representaria a concessão de efeito vinculante às decisões do STF prolatadas em processos subjetivos independentemente da observância dos requisitos estabelecidos pelo constituinte reformador, como, p. ex., o quorum especial de 2/3 (dois terços), a exigência de reiteradas decisões em matéria constitucional, e de controvérsia atual cujo retardo na prolação de uma decisão definitiva pelo STF acarrete grave insegurança jurídica e relevante multiplicação de processos (art. 103-A, caput e p. 1, CF/88).

Do exposto, percebe-se que a "interpretação" adotada pelo ilustre constitucionalista não tem lastro no fruto do exercício do poder constituinte derivado, ou mais precisamente, na resposta dada pelo Congresso Nacional ao problema da não-vinculação dos órgãos judiciais ao juízo de constitucionalidade prolatado pelo Supremo Tribunal. Pois bem: enquanto o primeiro afirma que todas as decisões do STF em controle incidental possuem per se efeitos gerais, a Reforma do Judiciário reservou tal eficácia especial às decisões do STF em controle incidental que hajam se convolado em súmula vinculante, mediante o preenchimento dos respectivos requisitos. Não se cogitando de violação a cláusulas pétreas, cumpre ao Judiciário seguir a orientação fixada pela Emenda Constitucional $n^{\circ} 45$, ainda que alvitre outra solução que lhe pareça mais conveniente sob a perspectiva da política judiciária. Assim, permissa venia, a tese da mutação constitucional do art. 52, X, da CF/88 significa a superação pelo Judiciário do juízo político do Congresso Nacional acerca do melhor conteúdo a ser atribuído à constituição, sem que se verifique, ou mesmo se cogite, de violação à cláusula pétrea, circunstância que revela uma ingerência indevida do Judiciário sobre o espaço reservado ao Legislativo para a atualização da constituição. ${ }^{59}$

\footnotetext{
${ }^{59}$ Para uma ampla e percuciente crítica à tese da mutação constitucional do art. 52, X, da CF/88, conferir STRECK, Lênio Luiz; OLIVEIRA, Marcelo Andrade Catoni; LIMA, Martônio Mont'Alverne Barreto. A Nova Perspectiva do Supremo Tribunal Federal sobre o Controle Difuso: Mutação Constitucional e Limites da Legitimidade da Jurisdição Constitucional. Disponível em <www.mundojuridico.adv.br>. Acesso em 04.04.2008.
} 
4.2 Há alguma inter-relação entre os papéis do Judiciário e do Congresso Nacional na mudança da Constituição? A que departamento estatal compete dar a última palavra sobre o sentido atual da Constituição?

O direito brasileiro apresenta, neste particular, singularidades que, apesar de darem azo a complexidades teóricas de enorme repercussão política, parecem ter sido pouco exploradas, especialmente pela já salientada tradição de analisar, de forma isolada e legalista, as alterações formais e informais da constituição. Dois fatores se destacam: (i) a possibilidade de revisão judicial de emendas constitucionais e (ii) a viabilidade de superação da jurisprudência constitucional do STF por emenda constitucional.

Um dos pontos que afastam a experiência brasileira da norte-americana e aproximam-na da germânica, ${ }^{60}$ é (i) a possibilidade de o Judiciário declarar a inconstitucionalidade de emendas constitucionais por violação aos limites ao poder de reforma, dentre os quais se destacam os limites materiais. Com efeito, o STF, desde 1926, por ocasião do julgamento do Habeas Corpus $\mathrm{n}^{\circ} 18.178,{ }^{61}$ vem afirmando, em tese, a sua competência para tal providência, embora somente na ADIn n ${ }^{\circ}$ 939-DF ${ }^{62}$ (1993) haja efetivamente declarado a inconstitucionalidade de dispositivos insertos em emenda constitucional (in casu a EC n ${ }^{\circ}$ 03/1993, que excluíra o IPMF da incidência do princípio da anterioridade tributária).

Em que pese à exacerbação da dificuldade contramajoritária do Judiciário no controle da constitucionalidade de emendas constitucionais, ante a maioria qualificada exigida para a sua aprovação, a auto-afirmação desta competência especial pelo STF se legitima democraticamente no contexto político-institucional brasileiro por diversos fatores: v.g., (a) a qualidade deliberativa do processo de reforma constitucional tende a ser inferior ao processo constituinte, já que no primeiro se verifica um "monopólio" dos Poderes Legislativo e Executivo e uma forte distância do povo, (b) o poder constituinte derivado se sujeita, freqüentemente, à influência de interesses partidários e corporativos (típicos da política ordinária), do que se extrai (c) a necessidade de tutela de elementos constitucionais essenciais em face de maiorias transitórias, etc.

\footnotetext{
${ }^{60}$ A Suprema Corte dos EUA considerou questões políticas todas as supostas inconstitucionalidades de emendas constitucionais que foram argüidas perante esta Excelsa Corte, embora a sua composição majoritária nunca haja afirmado a total insindicabilidade judicial das emendas constitucionais. Já o Tribunal Constitucional Alemão, desde o caso da "privacidade da comunicação", vem afirmando, em tese, a sua competência para controlar a constitucionalidade de emendas, apesar de nunca ter, efetivamente, exercido tal mister. V. TRIBE, Laurence. American Constitutional Law. Vol. I, 3 ed. New York: New York Foundation Press. 2000; MENDES, Gilmar Ferreira. Jurisdição Constitucional. 3 ed. São Paulo: Editora Saraiva, 1999

${ }^{61}$ BRASIL. Supremo Tribunal Federal. Habeas Corpus n 18178. Paciente: João Maria Xavier. Coator: Poder Executivo. Relator: Min. Hermenegildo de Barros, Disponível em: <http://www.stf.gov.br>. Acesso em: 12 jul. 2006. Revista Forense, 47, pp. 748/827.

${ }^{62}$ BRASIL. Supremo Tribunal Federal. Ação Direta de Inconstitucionalidade $n^{\circ}$ 939. Requerente: Confederação Nacional dos Trabalhadores no Comércio. Requerido: Congresso Nacional e Presidente da República. Relator: Min. Sidney Sanches, 15 de dezembro de 1993. Disponível em: <http://www.stf.gov.br>. Acesso em: 12 jul. 2006; RTJ - 151, pp. 755-841.
} 
Não se pode perder de vista, entretanto, que tais limites materiais foram descritos na forma de princípios vagos (i.e. "direitos e garantias individuais"), havendo o risco de o Judiciário, caso lhes confira uma exegese por demais elastecida, restringir excessivamente a abrangência do poder de reforma da constituição. Assim, devem ser estabelecidos parâmetros que delimitem o espaço de atuação legítima do Judiciário.

Preliminarmente, cumpre ser revisitada a teoria de Bruce Ackerman exposta no antecedente item. A aplicação das premissas da democracia dualista às mudanças constitucionais evidencia o risco de estabelecer-se uma associação necessária entre o teor das emendas e a vontade legítima da geração atual, pelo simples fato de ter-se observado o procedimento estabelecido no art. 60 da Constituição de 1988. A superação deste procedimento, apesar das supermaiorias exigidas, não deve, por si só, conferir ao Congresso Nacional um mandato para falar inequivocamente em nome do povo brasileiro.

Diante dos precitados casos de “ordinarização” da constituição e de entrincheiramento de privilégios, tal associação se afigura temerária. Por exemplo, a Emenda Constitucional nº 51/2006, ao efetivar no serviço público agentes de combate a endemias e agentes comunitários de saúde que não foram aprovados em concurso público, revela a influência de interesses corporativos no Congresso Nacional não apenas no âmbito da legislação ordinária, mas igualmente na deliberação referente às emendas constitucionais. Daí porque, embora advoguemos que o maior rigor do processo de reforma constitucional conduza, em regra, a uma postura de mais intenso judicial self-restraint no controle da constitucionalidade de emendas do que de leis, na hipótese de emendas veiculadoras de privilégios uma postura mais ativa do Judiciário se justifica, ante a premência da tutela dos princípios constitucionais da isonomia, da moralidade e da impessoalidade administrativa (e seus corolários, como a obrigatoriedade da aprovação em concurso público - art. 5, caput, e 37, caput e II, $\mathrm{CF} / 88$ ), inequivocamente insertos no rol de cláusulas pétreas (art. 60, p. 4, CF/88). Este é o primeiro standard interpretativo que se propõe.

Neste viés, convém destacar que, embora políticos empolgados com êxitos eleitorais conjunturais costumem atribuir às emendas que logrem aprovar o status de "revelação inescapável da vontade do povo”, de forma a negar a legitimidade democrática do controle da sua constitucionalidade por instituição contramajoritária, tal característica somente pode ser atribuída a emendas que, para além de respeitarem as cláusulas pétreas, tenham sido produzidas após um amplo e qualificado debate público, no qual tenham sido superados óbices institucionais impostos pela separação dos poderes, e não meramente os requisitos formais do processo de reforma constitucional. Enfim, a vontade do povo só há de manifestar-se legitimamente em períodos de excepcional mobilização cívica e de amplo debate público, como nos “momentos constitucionais” descritos por Ackerman.

Um outro parâmetro interpretativo relevante se consubstancia no dever de o Judiciário se pautar por uma postura de neutralidade política. De fato, ao aplicar princípios constitucionais de alta vagueza e densidade moral, não parece legítimo que juízes não eleitos atuem como guardiões de um modelo concreto de organização 
social estabelecido por uma geração passada, mormente quando a exata definição desse modelo é prejudicada pela baixa densidade semântica e pelo intenso desacordo moral dos respectivos paradigmas constitucionais. Ao contrário, os juízes devem se guiar pela razão pública, para, através de uma argumentação neutra em relação às diversas doutrinas abrangentes (morais, filosóficas, econômicas, etc.) e fincada em valores enraizados no coração das democracias constitucionais contemporâneas, preservar os elementos constitucionais essenciais da corrosão "pela legislação de maiorias transitórias ou, mais provavelmente, por interesses estreitos, organizados e bem-posicionados, muito hábeis na obtenção do que querem”, ${ }^{6}$

Assim, caso o Judiciário se limite a invalidar emendas constitucionais que transgridam as condições da democracia - assim entendidos os elementos constitucionais essenciais e a estrutura básica do Estado - ${ }^{64}$ não restringe, antes promove, a democracia, e, via de conseqüência, tal intervenção, embora contramajoritária, não pode ser tachada de antidemocrática. Por outro lado, caso a Corte se utilize de doutrina abrangente para preencher o conteúdo de princípios constitucionais, esbarrará no problema aqui, sim, insuperável - do déficit de legitimidade democrática dos juízes. De fato, como se justificar que agentes públicos não eleitos se substituam à maioria dos representantes do povo na eleição, p. ex., da "melhor doutrina econômica”? Nesta hipótese, revela-se cristalino que a jurisdição constitucional seria colocada a serviço do entrincheiramento constitucional da doutrina esposada (e, eventualmente, de posições de vantagem) por (de) grupos mais bem articulados perante este departamento estatal, os quais, por uma razão ou por outra, não obtiveram, ou temem não obter, êxito no processo político deliberativo.

Dois casos serão utilizados para demonstrar a pertinência da aplicação do parâmetro em tela no direito brasileiro. O primeiro se refere à argüição da inconstitucionalidade da "contribuição previdenciária dos inativos", instituída pela EC no 41/2003, no bojo das ADIs n ${ }^{\text {os }} 3128-7$ e 3105-8. ${ }^{65}$ Os autores das mencionadas ações alegaram, em abreviada síntese, que os servidores públicos inativos, ao preencherem os requisitos legais necessários para a aposentadoria no regime previdenciário instituído pela EC nº 20/98 (sob cuja égide não era possível a instituição de contribuição previdenciária sobre os proventos dos inativos),

\footnotetext{
${ }^{63}$ RAWLS. O Liberalismo Político. Op. cit., p. 284. Rawls adota perspectiva que se harmoniza com a democracia dualista de Bruce Ackerman, eis que vislumbra, sob a perspectiva da densidade moral, uma clivagem entre política constitucional e ordinária. Assim, defende a prerrogativa de a Corte Suprema controlar a constitucionalidade das leis e atos normativos, pois, apesar desta competência se afigurar contramajoritária, não se pode dizer antidemocrática, já que a vontade superior do povo, cristalizada na Constituição, autoriza esta intervenção, a par de a razão pública impedir a imposição, via Judiciário, da doutrina abrangente esposada por grupo mais bem articulado perante as Cortes. V. ACKERMAN, Bruce. We the people: foundations. Op. cit.; RAWLS, John. Op. cit., p. 284.

${ }^{64}$ No caso brasileiro, refere-se ao núcleo essencial da separação de poderes, do federalismo, do direito ao voto, e dos direitos fundamentais de diferentes gerações, em consonância ao disposto no art. 60, p, 4, da CF/88.

${ }^{65}$ DJ 18.02.2005, Ementário n 2180-3, p. 450 a 774, e DJ 18.02.2005, Ementário no 2180-2, pp. 123 a 416. As respectivas ações foram reunidas e mereceram idêntica decisão. V. BRASIL. Supremo Tribunal Federal. Ação Direta de Inconstitucionalidade $n^{0}$ 3128-7. Requerente: Associação Nacional dos Procuradores da República. Requerido: Congresso Nacional. Relator: Min. Ellen Gracie, 18 de agosto de 2004. Disponível em: <http://www.stf.gov.br>. Acesso em: 12 jul. 2006.
} 
incorporaram ao seu patrimônio jurídico o direito de não mais pagarem a referida contribuição. Assim, a EC n ${ }^{\circ} 41 / 2003$ teria malferido a cláusula constitucional da proteção do direito adquirido (art. 5, XXXVI, da CF/88) em relação aos servidores que se aposentaram antes da sua edição, garantia esta que, na forma da doutrina majoritária, é oponível não só ao legislador ordinário, mas também ao constituinte reformador, por se cuidar de direito individual, e, portanto, cláusula pétrea, nos termos do art. 60, $\S 4^{\circ}, \mathrm{IV}$, da CF/88. Tal tese foi acolhida pelos Ministros Carlos Ayres Britto, Celso de Mello, e Marco Aurélio Mello.

Contudo, o bom direito parece estar com os Ministros Cezar Peluso, Joaquim Barbosa, Gilmar Mendes, Carlos Mário Velloso, Sepúlveda Pertence e Nelson Jobim que, dentre outras assertivas, consignaram que a natureza tributária das contribuições previdenciárias afastava a tese do direito adquirido, ante a inexistência de direito adquirido a não-incidência de tributo nas hipóteses em que não houver norma constitucional específica que preveja imunidade tributária. Dados os limites deste estudo, não nos aprofundaremos no debate afeto à oponibilidade ou não dos direitos adquiridos às emendas constitucionais. $\mathrm{O}$ aspecto da decisão em exame que merece ser destacado consiste no risco de uma exegese excessivamente abrangente das cláusulas pétreas acabar por promover uma petrificação de privilégios, em esvaziamento da pretensão transformadora da Constituição de 1988.

Pois bem. Em que pese a todos os riscos eleitorais inerentes à adoção de medida tão impopular, os Poderes Executivo e Legislativo (este por maioria qualificada), através da EC. $n^{\circ}$ 41/2003, deliberaram que os aposentados também deveriam pagar contribuição previdenciária, com o escopo de minorar o imenso rombo do regime próprio de previdência social, cuja injustiça, segundo Luís Roberto Barroso, revela-se "por uma perversa solidariedade social às avessas, na qual os mais pobres financiam os mais abastados."

Tal injustiça é comprovada pelos argumentos “pré-jurídicos” desenvolvidos por Barroso, a saber: (i) em países desenvolvidos, como a França e a Alemanha, os proventos e as pensões são inferiores aos valores percebidos pelo servidor em atividade (no Brasil, as pensões e os proventos são fixados no valor da última remuneração, sendo que os valores médios das aposentadorias são os seguintes: Executivo - R\$ 2.282, Ministério Público - R\$ 12.571, Legislativo R\$ 7.900, Judiciário R\$ 8.027, e Militares R\$ 4.275); (ii) do ponto de vista da lógica do sistema, a não cobrança de contribuição previdenciária dos servidores inativos importaria em um aumento real correspondente à alíquota de contribuição (11\%, atualmente) por ocasião da passagem para a inatividade, servindo como um incentivo para aposentadorias precoces; (iii) até a $\mathrm{EC} \mathrm{n}^{0}$ 3/93, o regime não era contributivo, de modo que boa parte dos aposentados não contribuiu para o regime próprio, ou contribuiu por menos de dez anos; (iv) boa parte dos aposentados sob o regime próprio ingressou no sistema mediante a conversão dos seus empregos em cargos

${ }^{66}$ BARROSO, Luís Roberto. Constitucionalidade e legitimidade da Reforma da Previdência (ascensão e queda de um regime de erros e privilégios). Temas de Direito Constitucional. Tomo III. Rio de Janeiro: Renovar, 2005, p. 168. 
públicos, após haverem contribuído a maior parte do tempo para o regime geral, sobre base de cálculo muito inferior aos proventos percebidos; (v) as regras anteriores à EC $n^{\circ}$ 20/98 permitiam aposentadorias precoces; (vi) além de fatores conjunturais, como o aumento da expectativa de vida e a redução dos quadros no serviço público. ${ }^{67}$

Sendo o regime próprio de previdência custeado pelas contribuições e pelos orçamentos dos entes federativos, soa óbvio que o imenso déficit, ${ }^{68}$ causado pela insuficiência das primeiras fontes de custeio, é suportado pelos últimos, de modo que, na verdade, dilui-se nos impostos que são pagos pela população em geral. $^{69}$ Daí a “solidariedade social às avessas”, salientada por Barroso.

Pelo exposto, o corajoso juízo político empreendido por um governo de "esquerda” e por uma supermaioria parlamentar para a correção deste mecanismo concentrador de renda não deve ser substituído pelo juízo do Judiciário. Com efeito, caso o Judiciário se paute pela razão pública e pelos princípios democrático e da isonomia, parece impertinente que anule a referida decisão política, pois uma tal exegese ampliativa conferida à proteção superconstitucional do direito adquirido, para além de não ter lastro na dogmática jurídica (ante a inexistência de direito adquirido à não-incidência de tributo, afora as hipóteses de imunidade constitucional), representaria um ativismo judicial destinado a congelar um sistema previdenciário marcado por distorções e privilégios, que em nada se relaciona com as alvitradas condições da democracia.

As razões antes expendidas não conduzem à defesa de uma concepção de minimalismo judicial para o controle da constitucionalidade de emendas. Ainda que se sustente que o Judiciário deva atuar com maior auto-restrição no controle da constitucionalidade de emendas do que de leis, ante o maior rigor do primeiro procedimento, admite-se um "ativismo judicial” na fiscalização das emendas que avancem contra as alvitradas condições da democracia.

Cite-se, a propósito, a ADIN no 1946/DF, ${ }^{70}$ em cujo processo o STF procedeu à interpretação conforme a constituição do art. 14 da $\mathrm{EC} \mathrm{n}^{\circ}$ 20/98, de modo a afastar a exegese que incluía a licença à gestante no teto de benefícios previdenciários por ele instituído. Note-se que se afigurava, a princípio, juridicamente possível a interpretação que sujeitava a licença à gestante ao mencionado limite, à vista de o art. 14 da EC 20/98 não estabelecer distinções entre os benefícios previdenciários que deveriam

\footnotetext{
${ }^{67}$ BARROSO. Op. cit., pp. 201/202.

${ }^{68}$ Não é de causar surpresa, portanto, que o regime próprio de previdência, apesar de congregar "apenas" 3,2 milhões de inativos e pensionistas, tenha déficit anual de R 39 bilhões (em relação ao valor arrecadado com contribuições), enquanto o regime geral, com seus 19 milhões de beneficiários, tem déficit anual de “apenas” R\$ 17 bilhões. Tais dados referem-se a 2002 (utilizado como referência por se cuidar do ano anterior á aprovação da EC nº 41/2003), e foram colhidos do site do Ministério da Previdência Social por BARROSO. Op. cit., p. 174.

${ }^{69}$ Ver, a propósito, o ADIn n ${ }^{\circ}$ 3128-7, DJ 18.02.2005, Ementário n ${ }^{\circ}$ 2180-3, Voto do Ministro Carlos Velloso, p. 686.

${ }^{70}$ BRASIL. Supremo Tribunal Federal. Ação Direta de Inconstitucionalidade nº 1946. Requerente: Partido Socialista Brasileiro. Requerido: Ministro de Estado da Previdência e Assistência Social e Mesas da Câmara dos Deputados e do Senado Federal. Relator: Min. Sidney Sanches, 03 de abril de 2003. Disponível em: <http://www.stf.gov.br>. Acesso em: 12 jul. 2006. RTJ 186: 472/479.
} 
ceder ao teto, e em razão de a questão da proteção à gestante vir sendo tratada desde 1932, e, mais claramente, a partir de 1974, “cada vez menos como um encargo trabalhista (do empregador), e cada vez mais como encargo de natureza previdenciária."71 A Constituição de 1988, por sua vez, manteve a natureza previdenciária do referido benefício, ao incluir a proteção à maternidade entre os direitos sociais arrolados no art. $7^{\circ}$, e entre os benefícios previdenciários arrolados no art. 201 da CF (inciso II).

Tal interpretação, contudo, padece de inequívoca inconstitucionalidade, já que, caso se aplicasse o teto à licença-gestante, ter-se-ia como corolário imputar à Previdência Social o dever de arcar com apenas R\$ 1.200,00 (mil e duzentos reais), competindo ao empregador pagar o restante, na hipótese de o salário da mulher superar o referido valor. A conseqüência inevitável desta desastrosa interpretação seria "conclamar o empregador a oferecer à mulher-trabalhadora, quaisquer que sejam as suas aptidões, salário nunca superior a R\$ 1.200,00, para não ter de responder pela diferença." Tal interpretação, evidentemente, propiciaria "a discriminação que a Constituição buscou combater, quando proibiu diferença de salários, de exercício de funções e de critérios de admissão, por motivo de sexo (art. $7^{\circ}$, inc. XXX, da CF/88),"72 Em poucas palavras: a limitação da licença gestante ao teto da Previdência Social redundaria em um tratamento desigual entre homens e mulheres no mercado de trabalho, desconsiderando o dever do Estado de tratar homens e mulheres com "igual consideração e respeito”.

Da análise combinada dos casos trazidos à baila, pode-se concluir que, caso o Judiciário não limite a sua atuação no controle da constitucionalidade das emendas à tutela das condições da democracia, a sua intervenção qualificar-se-á como antidemocrática, instituindo verdadeiro "governo dos mortos sobre os vivos", pois manterá a maioria atual vinculada a um modelo de sociedade estabelecido pela geração constituinte. Mais grave ainda se afigura a invalidação de emendas para, em contrariedade à deliberação supermajoritária da geração atual, petrificar privilégios de uma minoria entrincheirados no passado, já que neste caso o direito constitucional se desvincularia do seu propósito fundamental de estabilizar as regras do jogo político e de proteger direitos fundamentais, para uma espúria função de congelamento do status quo. Os efeitos maléficos da preservação pelo Judiciário de uma constituição que não mais condiz com os desígnios dos vivos são previsíveis: descumprimento sistemático da constituição ou ruptura institucional, com repercussões deletérias sobre a sua força normativa e sobre a segurança jurídica, respectivamente.

Entretanto, há um fator que, se bem utilizado e compreendido, pode minimizar estes riscos: o efeito vinculante das decisões do STF se aplica aos "demais órgãos judiciais” e aos órgãos administrativos das três esferas de governo”, mas não ao Legislativo. $^{73}$ Assim, caso o Parlamento aprove diretriz normativa idêntica àquela declarada inconstitucional, não há que se falar em descumprimento de decisão do STF, e, por conseguinte, de cabimento de reclamação. Ao contrário, a aprovação de

\footnotetext{
${ }^{71}$ Excerto retirado da emenda do mencionado acórdão.

${ }^{72}$ Trechos colhidos do voto condutor do Min. Sydney Sanches.

${ }^{73}$ Vide o art. 102, p. 2, da CF/88, e art. 28, p. único, da Lei ${ }^{\circ}$ 9.868/99.
} 
norma idêntica à declarada inconstitucional, salvo em casos excepcionais, deve ser considerada como uma reabertura do debate sobre a constitucionalidade de determinada diretriz normativa, ainda que o STF possa voltar a declará-la inconstitucional em nova Ação Direta de Inconstitucionalidade que venha a ser proposta.

Consoante salientado no início desta seção, (ii) a possibilidade de o Congresso Nacional aprovar Emenda Constitucional superadora de decisão do STF agrega complexidade à análise dos lugares ocupados pelos Poderes Legislativo e Judiciário na atualização do sentido da constituição. Embora tal prerrogativa possa causar estranheza, por supostamente atritar com a independência do órgão de cúpula do Judiciário brasileiro, esta impressão inicial não procede.

Um simples silogismo comprova o exposto: se a função precípua do STF é atuar como "guardião da constituição", e se compete à maioria de três quintos das Casas Legislativas alterar formalmente a constituição, a princípio não há óbice a que, aprovando-se emenda que altere a norma constitucional que fundamentara decisão do STF, acabe-se por conduzir, ainda que por via reflexa, à modificação da jurisprudência constitucional da Suprema Corte. Durante os vinte anos de vigência da Constituição de 1988 tivemos alguns exemplos deste fenômeno.

Dentre os mais importantes, cite-se a (i) EC 19/98 que "inseriu” as vantagens de caráter pessoal no cômputo do teto remuneratório, em oposição à decisão proferida na ADI $n^{\circ} 14,{ }^{74}$ na qual o STF afirmara que tais verbas não se achavam incluídas na expressão "quaisquer vantagens" contida na redação original do art. 37, XI, da CF/88. Já a (ii) EC nº 29/2000 previu a progressividade do IPTU em razão do valor do imóvel e a diferenciação das suas alíquotas de acordo com a localização e o uso do imóvel, alterando a jurisprudência do STF que só admitia a progressividade do IPTU no tempo para o atendimento da finalidade extrafiscal de adequar o uso da propriedade urbana à sua função social, hipótese prevista no art. 182, p. 4, II, da $\mathrm{CF} / 88$. Ademais, a EC n ${ }^{\circ}$ 39/2002 criou a contribuição para o custeio do serviço de iluminação pública, em nítida resposta às reiteradas decisões nas quais o STF invalidara taxas de custeio da iluminação pública, sob o argumento de que não se tratava de serviço público específico e divisível.

Por fim, cabe indagar: pode o Congresso Nacional reverter a interpretação conferida pelo STF a qualquer norma constitucional? Ao nosso ver não, eis que não se afigura possível a superação por emenda constitucional de interpretação dada pelo STF às cláusulas pétreas, sob pena de as mesmas não cumprirem a sua função de limites materiais efetivos ao poder de reforma constitucional. Nesta hipótese, parece que só uma nova manifestação do poder constituinte originário autorizaria a reversão da jurisprudência constitucional em tela. Todavia, tendo em vista a já salientada não aplicação do efeito vinculante das decisões do STF ao Poder Legislativo, não se pode afastar a possibilidade de ser aprovada emenda constitucional em sentido contrário à interpretação conferida pelo STF à cláusula pétrea, e o próprio Supremo, em Ação

${ }^{74}$ BRASIL. Supremo Tribunal Federal. Ação Direta de Inconstitucionalidade n ${ }^{\circ}$ 14. Requerente: Associação dos Magistrados Brasileiros - AMB. Requerido: Congresso Nacional e Presidente da República. Relator: Min. Célio Borja, 13 de setembro de 1989. Disponível em: <http://www.stf.gov.br>. Acesso em: 13 set. 2007. 
Direta de Inconstitucionalidade contra ela proposta, alterar a sua jurisprudência para julgá-la constitucional.

Em síntese, pode-se afirmar que, caso o Judiciário se limite a invalidar emendas que violem as condições da democracia (direitos fundamentais de distintas "gerações" e a estrutura básica do Estado), e, caso o Congresso Nacional se restrinja a superar a interpretação dada pelo STF a normas constitucionais que não tenham o status de cláusula pétrea, será dado um passo importante para o atingimento de um ponto ótimo entre os consensos constitucionais e o pluralismo político, entre estabilidade e adaptabilidade da constituição. Isto porque, a intervenção contramajoritária do Judiciário estará jungida à preservação de elementos constitucionais essenciais e da estabilidade do processo político em face da vontade política do momento, sem criar obstáculos para que os canais de deliberação democrática promovam alterações substanciais no projeto de desenvolvimento social concebido pela geração constituinte.

Subsiste, entretanto, o risco de os Poderes Judiciário e Legislativo não se restringirem aos espaços antes demarcados, sobretudo pela dificuldade de se distinguir concretamente tais áreas de atuação. Neste caso, o risco de embates entre os "poderes" e de ruptura constitucional pode ser atenuado por uma proposta de diálogo institucional: o debate acerca de um eventual excesso do Judiciário no controle da constitucionalidade de determinada emenda pode ser reaberto pela edição de nova emenda, ante a não aplicação do efeito vinculante ao Legislativo; por outro lado, uma emenda constitucional que supere jurisprudência do STF garantidora do núcleo essencial de cláusula pétrea pode ser declarada inconstitucional pelo STF, ante o cabimento do controle da constitucionalidade de emendas constitucionais no Brasil. Caso, todavia, os poderes Legislativo e Judiciário não logrem obter um consenso sobre os seus âmbitos de atuação, instala-se o impasse constitucional a que alude Ackerman, o qual somente será resolvido quando um dos “poderes” aquiescer à posição defendida pelo seu oponente.

\section{SÍNTESE CONCLUSIVA}

- É cabível a adoção da premissa da democracia dualista do direito brasileiro?

Sim. Depreende-se do processo constituinte brasileiro e do teor da Carta de 1988 a aplicabilidade em terra brasilis da idéia de que as constituições resultam de um processo deliberativo superior ao ordinário, em virtude da especial mobilização cívica e da sua qualidade intrínseca, decorrente da retirada de elementos constitucionais essenciais e das regras básicas do jogo político do dia-a-dia da política ordinária. Entretanto, os casos de entrincheiramento de privilégios na Constituição de 1988 não nos devem conduzir ao equívoco de conferir aos dispositivos constitucionais uma "aura de santidade".

- Quais fatores incrementam o grau de rigidez de um sistema constitucional?

Inicialmente, destacam-se a extensão, a abrangência e o detalhamento do texto constitucional, visto que uma constituição longa, densa e composta predominantemente por regras retira um amplo e pormenorizado leque de matérias do poder deliberativo ordinário do Parlamento, sujeitando a sua alteração às supermaiorias necessárias à aprovação de uma emenda. Ademais, o nível de dificuldade do processo de reforma 
constitucional também agrega rigidez à constituição, na medida em que, quanto mais difícil for a aprovação de uma emenda constitucional, mais se prestigia a estabilidade dos consensos constitucionais em detrimento da adaptabilidade da constituição e do pluralismo político. Uma análise consistente do grau de rigidez de um sistema constitucional pressupõe, contudo, que tais fatores sejam combinados.

- É possível o estabelecimento de uma relação entre o grau de dificuldade do processo de reforma e a intensidade do emprego dos métodos de alteração formal e informal da constituição?

Sim. É intuitivo que, quanto mais difícil for a aprovação de emendas constitucionais, mais restrita deverá ser a utilização deste método (o qual é, em regra, dominado pelo Legislativo). Se as mudanças ocorridas na realidade devem se refletir no bojo de uma constituição normativa, um baixo índice de emendas revela que tais mudanças estão sendo veiculadas por mutação constitucional (cuja primazia tende a ser do Judiciário). Do exposto se infere que a discussão afeta à relação entre rigidez constitucional e democracia desemboca na questão relativa aos papéis desempenhados pelos Poderes Legislativo e Judiciário na atualização da constituição.

- Pode-se distinguir as mudanças constitucionais viáveis de implementação por decisão judicial daquelas que só podem ser veiculadas por emenda constitucional?

Devem ser afastadas as teses que (i) afirmam a exclusividade das emendas procederem a alterações constitucionais, ou que sustentam que a distinção entre tais processos reside (ii) na relevância da alteração constitucional promovida ou (iii) na função desempenhada por cada um deles, v.g.: iniciar, impedir, sancionar ou efetivar mudanças constitucionais ou mesmo preservar o status quo. A distinção que nos parece mais adequada se funda no fato de a atualização da constituição pelo Judiciário se jungir aos limites semânticos do texto constitucional (cuida-se, portanto, de atividade interpretativa), enquanto as emendas constitucionais podem alterar ou revogar, efetivamente, determinado dispositivo constitucional. Ademais, caso não se vislumbrar lesão aos limites ao poder de reforma, o Judiciário deve prestigiar a orientação veiculada em emenda constitucional acerca do melhor conteúdo atual da Constituição. Na vertente hipótese, não deve o juiz substituir o juízo político do Congresso, ainda que vislumbre outro conteúdo constitucional que lhe pareça mais adequado.

- Há alguma inter-relação entre as emendas constitucionais e a atualização informal da constituição por decisão judicial? Em caso positivo, a que departamento estatal (Legislativo ou Judiciário) compete a última palavra acerca do sentido atual da constituição?

Neste particular, há singularidades pouco exploradas do sistema brasileiro, a saber: (i) a possibilidade de revisão judicial de emendas constitucionais e (ii) a viabilidade de superação da jurisprudência constitucional do STF por emenda constitucional.

Quanto ao primeiro fator (i), sustenta-se que, embora o maior rigor do processo de reforma constitucional conduza, em regra, a uma postura de mais intensa auto-restrição judicial no controle da constitucionalidade de emendas do que de leis, na hipótese de emendas veiculadoras de privilégios uma postura mais ativa do 
Judiciário se justifica. Ademais, deve o Judiciário atuar de forma politicamente neutra, para, no âmbito de um consenso sobreposto entre doutrinas abrangentes e razoáveis, preservar apenas os elementos constitucionais essenciais e as regras básicas de estruturação do Estado de maiorias transitórias. Mediante a aplicação destes dois parâmetros interpretativos, acredita-se que o Judiciário poderá zelar pela estabilidade de consensos constitucionais mínimos sem prejuízo do poder de autodeterminação coletiva do povo, e sem permitir que grupos de interesse se utilizem da rigidez constitucional para petrificar privilégios ou visões de mundo particulares.

Quanto ao segundo elemento (ii), convém destacar que o Congresso Nacional só deve superar, via emenda constitucional, jurisprudência do STF que recaia sobre norma constitucional que não ostente a natureza de cláusula pétrea, já que a última se consubstancia em limite material ao poder de reforma da constituição. Há, entretanto, o risco de os Poderes Judiciário e Legislativo, na prática, não se restringirem aos espaços antes demarcados. Neste caso, se formula uma proposta de diálogo institucional para a definição do sentido atual da constituição: o debate acerca de um eventual excesso do Judiciário no controle da constitucionalidade de emenda pode ser reaberto pela edição de nova emenda, ante a não aplicação do efeito vinculante das decisões do STF ao Legislativo; por outro lado, uma emenda constitucional que supere jurisprudência do STF garantidora do núcleo essencial de cláusula pétrea pode ser declarada inconstitucional pelo STF, ante o cabimento do controle da constitucionalidade de Emendas Constitucionais no Brasil.

\section{BIBLIOGRAFIA}

ACKERMAN, Bruce. We the people: foundations. Cambridge: The Belknap University Press, 1991.

Higher Lawmaking. In: LEVINSON, Sanford. Responding to Imperfection - The Theory and Practice of Constitutional Amendment, Princeton: Princeton University Press, 1995.

ALEXY, Robert. Teoría de los Derechos Fundamentales. Madrid: Centro de Estudios Constitucionales, 1997.

ÁVILA, Humberto Bergman. Teoria dos Princípios - da definição à aplicação dos princípios jurídicos. 5. ed. São Paulo: Malheiros Editores, 2006.

BARCELlOS, Ana Paula de. Ponderação, Racionalidade e Atividade Jurisdicional. Rio de Janeiro: Renovar, 2005.

BARROSO, Luís Roberto. Doze anos da Constituição Brasileira de 1988 (Uma breve e acidentada história de sucesso). Temas de Direito Constitucional. Rio de Janeiro: Renovar, 2001. Interpretação e Aplicação da Constituição. 3 ed. Rio de Janeiro: Renovar, 1999.

Constitucionalidade e legitimidade da Reforma da Previdência (ascensão e queda de um regime de erros e privilégios). Temas de Direito Constitucional. Tomo III. Rio de Janeiro: Renovar, 2005.

BAYÓN, Juan Carlos. Derechos, democracia y constitución. In: LAPORTA, Francisco. Constitución: problemas filosóficos. Madrid: Centro de Estudios Políticos y Constitucionales, 2003, p. 410.

BRASIL. Supremo Tribunal Federal. Habeas Corpus n 18178. Paciente: João Maria Xavier. Coator: Poder Executivo. Relator: Min. Hermenegildo de Barros, Disponível em: <http://www.stf.gov.br>. Acesso em: 12 jul. 2006. 
BRASIL. Supremo Tribunal Federal. Ação Direta de Inconstitucionalidade nº 939. Requerente: Confederação Nacional dos Trabalhadores no Comércio. Requerido: Congresso Nacional e Presidente da República. Relator: Min. Sidney Sanches, 15 de dezembro de 1993. Disponível em: <http://www.stf.gov.br>. Acesso em: 12 jul. 2006.

BRASIL. Supremo Tribunal Federal. Ação Direta de Inconstitucionalidade no ${ }^{\circ} 1946$. Requerente: Partido Socialista Brasileiro. Requerido: Ministro de Estado da Previdência e Assistência Social e Mesas da Câmara dos Deputados e do Senado Federal. Relator: Min. Sidney Sanches, 03 de abril de 2003. Disponível em: <http://www.stf.gov.br>. Acesso em: 12 jul. 2006. RTJ 186: 472/479.

BRASIL. Supremo Tribunal Federal. Ação Direta de Inconstitucionalidade $n^{\circ} 14$. Requerente: Associação dos Magistrados Brasileiros - AMB. Requerido: Congresso Nacional e Presidente da República. Relator: Min. Célio Borja, 13 de setembro de 1989. Disponível em: $<$ http://www.stf.gov.br>. Acesso em: 13 set. 2007.

BRASIL. Supremo Tribunal Federal. Ação Direta de Inconstitucionalidade n ${ }^{\circ} 3128-7$. Requerente: Associação Nacional dos Procuradores da República. Requerido: Congresso Nacional. Relator: Min. Ellen Gracie, 18 de agosto de 2004. Disponível em: <http://www.stf.gov.br>. Acesso em: 12 jul. 2006.

BRITO. Miguel Nogueira. A Constituição Constituinte - Ensaio sobre o Poder de Revisão da Constituição. Coimbra: Coimbra Editora, 2000, p. 39/40.

BRANDÃO, Rodrigo. As culturas liberal e democrática de proteção dos direitos individuais no constitucionalismo clássico. In: Revista de Informação Legislativa $n^{\circ}$ 175, ano 44 (jul./set. 2007). Brasília: Senado Federal, Subsecretaria de Edições Técnicas, pp. 233/268.

BRYCE, James. Constitutiones flexibles y Constitutiones rígidas. Madrid: 1963.

CANOTILHO, José Joaquim Gomes. Direito Constitucional. Coimbra: Almedina, 1992.

CLÉVE, Clemerson Merlin. A Fiscalização Abstrata da Constitucionalidade no Direito Brasileiro. 2. ed. São Paulo: Editora Revista dos Tribunais, 2000.

DWORKIN, Ronald. Levando os Direitos a Sério. São Paulo: Martins Fontes, 2002. Law's Empire. London: Duckworth, 1986.

ELSTER, Jon. Ulysses and the Sirens: studies in rationality and irracionality. Great Britain: Cambridge University Press.

Constitucionalism in Eastern Europe: an introduction. University of Chicago Law Review 58 (1991): 470.

FERRAZ, Ana Cândida Cunha. Processos informais de mudança da Constituição. São Paulo: Editora Max Limonad, 1986.

FIORAVANTI, Maurizio. Los derechos fundamentales: apuntes de la historia de las constituciones. 4 ed. Madrid: Editorial Trotta, 2003.

HOLMES, Stephen. Pre-commitment and the paradox of democracy. In: HOLMES, Stephen. Passions and constraints: on the theory of liberal democracy. Chicago: University of Chicago Press, pp. 134/178.

LA TORRE, Massimo. Theories of Legal Argumentation and Concepts of Law. An Approximation. Ratio Iuris. Vol. 15, n. 4. December, 2002, pp. 377-402.

LEVINSON, Sanford. "How Many Times Has the United States Constitution Been Amended? (A) <26; (B) 26; (c) 27; (d) > 27: Accounting for Constitutional Change”. In: LEVINSON, Sanford. Responding to Imperfection - The Theory and Practice of Constitutional Amendment, Princeton: Princeton University Press, 1995. 
LOEWENSTEIN, Karl. Teoría de la constitución. 2 ed. Barcelona: Editorial Ariel, Barcelona, 1976.

LUTZ, Donald. Toward a Theory of Constitutional Amendment. In: LEVINSON, Sanford. Responding to Imperfection - The Theory and Practice of Constitutional Amendment, Princeton: Princeton University Press, 1995.

MENDES, Gilmar Ferreira. Jurisdição Constitucional. 3 ed. São Paulo: Editora Saraiva, 1999. PEREIRA, Jane Reis Gonçalves. Interpretação Constitucional e Direitos Fundamentais. Rio de Janeiro: Renovar, 2006.

PIÇARRA, Nuno. A Separação de Poderes como Doutrina e Princípio Constitucional. Coimbra: Coimbra editora. 1989.

PRIETO SANCHÍS, Luis. Neoconstitucionalismo y ponderación judicial. In: CARBONELL, Miguel. Neoconstitucionalismo(s), Madrid: editorial Trotta, 2003.

RAWLS, John. O Liberalismo Político. 2. ed. São Paulo: Editora Ática, 2000.

SARMENTO, Daniel. A Ubiqüidade Constitucional: os dois lados da moeda. Revista de Direito do Estado n. 2, 2006.

STRECK, Lênio Luiz; OLIVEIRA, Marcelo Andrade Catoni; LIMA, Martônio Mont’Alverne Barreto. A Nova Perspectiva do Supremo Tribunal Federal sobre o Controle Difuso: Mutação Constitucional e Limites da Legitimidade da Jurisdição Constitucional. Disponível em $<$ www.mundojuridico.adv.br>. Acesso em 4.abril.2008.

SUNSTEIN, Cass; HOLMES, Stephen. "The Politics of Constitutional Revision in Eastern Europe”. In: SANFORD, Levinson. Responding to Imperfection - The Theory and Practice of Constitutional Amendment. Princeton: Princeton University Press, 1995.

THAYER, James Bradley. The origin and the scope of the American doctrine of constitutional law. Harvard Law Review 129 (1893).

TRIBE, Laurence. American Constitutional Law. Vol. I, 3 ed. New York: New York Foundation Press. 2000.

VILE, John. R. Constitutional Change in the United States - A comparative study of the role of constitutional amendments, judicial interpretations, and legislative and executive actions. Connecticut: Praeger, 1994.

VEGA, Pedro de. La Reforma Constitucional y la Problematica del Poder Constituyente. Madrid: Tecnos, 2000 VEGA, Pedro de. La Reforma Constitucional y la Problematica del Poder Constituyente. Madrid: Tecnos, 2000.

WALDRON, Jeremy. Law and disagreement. Oxford: Oxford University Press, 2004. 